\title{
1 Oxygen isotope records of Holocene climate variability in the Pacific Northwest
}

3 Byron A. Steinman ${ }^{1 *}$, David P. Pompeani ${ }^{2}$, Mark B. Abbott ${ }^{2}$, Joseph D. Ortiz ${ }^{3}$, Nathan D.

$4 \quad$ Stansell $^{4}$, Matthew S. Finkenbinder ${ }^{2}$, Lorita Mihindukulasooriya ${ }^{5}$, Aubrey L. Hillman ${ }^{2}$

5

${ }^{1}$ Large Lakes Observatory and Department of Earth and Environmental Sciences, University of

7 Minnesota Duluth, Duluth, MN, USA

$8{ }^{2}$ Department of Geology and Environmental Science, University of Pittsburgh, Pittsburgh, PA, 9 USA

$10 \quad{ }^{3}$ Department of Geology, Kent State University, Kent, OH, USA

$11{ }^{4}$ Department of Geology and Environmental Geosciences, Northern Illinois University, De Kalb,

12 Illinois, USA

$13{ }^{5}$ Department of Natural Sciences, Northwest Missouri State University, Maryville, Missouri, 14 USA

*Corresponding author

\section{Abstract}

Oxygen isotope $\left(\delta^{18} \mathrm{O}\right)$ measurements of authigenic carbonate from Cleland Lake (southeastern British Columbia), Paradise Lake (central British Columbia), and Lime Lake (eastern Washington) provide a 9,000 year Holocene record of precipitation-evaporation balance variations in the Pacific Northwest. Both Cleland Lake and Paradise Lake are small, surficially closed-basin systems with no active inflows or outflows. Lime Lake is surficially open with a seasonally active overflow. Water isotope values from Cleland and Paradise plot along the local evaporation line, indicating that precipitation-evaporation balance is a strong influence on lake hydrology. In contrast, Lime Lake water isotope values plot on the local meteoric water line, signifying minimal influence by evaporation. To infer past hydrologic balance variations at a high temporal resolution, we sampled the Cleland, Paradise, and Lime Lake sediment cores at 1$60 \mathrm{~mm}$ intervals $(\sim 3-33$ years per sample on average) and measured the isotopic composition of

31 fine-grained $(<63 \mu \mathrm{m})$ authigenic $\mathrm{CaCO}_{3}$ in each sample. Negative $\delta^{18} \mathrm{O}$ values, which indicate 
wetter conditions in closed-basin lakes, occur in Cleland Lake sediment from 7,600 to 2,200 years before present ( $\mathrm{yr} \mathrm{BP}$ ), and are followed by more positive $\delta^{18} \mathrm{O}$ values, which suggest drier conditions, after 2,200 yr BP. Highly negative $\delta^{18} \mathrm{O}$ values in the Cleland Lake record centered on $\sim 2,400$ yr BP suggest that lake levels were high (and that the lake may have been overflowing) at this time as a result of a substantially wetter climate. Similarly, Paradise Lake sediment $\delta^{18} \mathrm{O}$ values are relatively low from 7,600 to 4,000 yr BP and increase from $\sim 4,000$ to $3000 \mathrm{yr}$ BP and from $2,000 \mathrm{yr}$ BP to present, indicating that climate became drier from the middle through the late Holocene. The $\delta^{18} \mathrm{O}$ record from Lime Lake, which principally reflects changes in the isotopic composition of precipitation, exhibits less variability than the closedbasin lake records and follows a generally increasing trend from the mid-Holocene to present. These results are consistent with several proximal reconstructions of changes in lake-level, precipitation amount, and precipitation isotopic composition and may also reflect the establishment modern El Niño Southern Oscillation (ENSO) variability in the late Holocene, as inferred from proxy evidence of synoptic ocean-atmosphere changes in the Pacific basin. Results from mid-Holocene (6,000 yr BP) climate model simulations conducted as part of the Paleoclimate Modeling Intercomparison Project Phase 3 (PMIP3) indicate that in much of western North America, the cold season (October-March) was wetter and the warm season (April-September) was considerably drier relative to the late Holocene, leading to an overall drier climate in western North America with enhanced hydroclimatic seasonality. This is consistent with inferences from the Cleland and Paradise $\delta^{18} \mathrm{O}$ records, which lake modeling experiments indicate are strongly influenced by cold season precipitation-evaporation balance. This also explains apparent inconsistencies between the lake $\delta^{18} \mathrm{O}$ records and other proxies of hydroclimatic change from the greater Pacific Northwest region that are less sensitive to cold season climate and thus indicate relatively drier conditions during the mid-Holocene. The abrupt negative excursion at $\sim 2,400 \mathrm{yr} \mathrm{BP}$ in the Cleland Lake $\delta^{18} \mathrm{O}$ data, as well as the marked shift to more positive values after this time, demonstrate that gradual changes in ocean-atmosphere dynamics can produce abrupt, non-linear hydroclimate responses in the interior regions of western North America.

Key words: Paleoclimate, Global Change, Oxygen Isotopes, Drought, Lake Sediment, Holocene 


\section{Introduction}

Changes in the Pacific and Atlantic ocean-atmosphere systems during the Holocene produced substantial variations in the climate of western North America. Currently, the El Niño Southern Oscillation (ENSO) (Brown and Comrie, 2004; Cayan et al., 1999, 1998; Dettinger et al., 1998; McCabe and Dettinger, 2002, 1999; Wise, 2010), the closely associated Pacific Decadal Oscillation (PDO) (Barlow et al., 2001; Biondi et al., 2001; Bond and Harrison, 2000; Gedalof, 2002; Hare and Mantua, 2001; Hidalgo, 2004; MacDonald and Case, 2005; Mantua and Hare, 2002; Mantua et al., 1997; Sung et al., 2014; Whitfield et al., 2010), and the Northern Annular Mode (NAM) (which is expressed through the Arctic Oscillation or AO) (McAfee and Russell, 2008; Wallace and Thompson, 2002; Wang et al., 2006) are the primary drivers of North American hydroclimate variability on inter-annual to multidecadal timescales. These synoptic climate systems affect the strength and trajectory of the westerly winds and summer monsoonal air masses that deliver water vapor from the Pacific and Atlantic basins to the interior of North America. Other modes of ocean-atmosphere variability, such as the Pacific North American Pattern (Ge et al., 2009; Leathers and Palecki, 1992; Leathers et al., 1991; Lee et al., 2012; Liu et al., 2014, 2013, 2011; Minobe and Mantua, 1999; Trouet and Taylor, 2010), and the Atlantic Multidecadal Oscillation (AMO) (Enfield et al., 2001; Feng et al., 2008; Hidalgo, 2004; Kim et al., 2004; McCabe et al., 2008, 2004; Mo et al., 2009), influence climate in North America and are related to the aforementioned climate modes either directly or through global teleconnections. For example, various lines of research have revealed close relationships between ENSO and the PDO (Di Lorenzo et al., 2010; Newman et al., 2003; Verdon and Franks, 2006; Vimont, 2005) as well as connections between predominant climate modes in the Pacific and Atlantic basins (e.g., ENSO and AMO) (Alexander et al., 2002; Dong et al., 2006; Timmermann et al., 2007; Zhang and Delworth, 2007). Our current understanding of how these modes of variability influence western North America is based largely on analyses of historical observations, which typically span less than a century, and climate model simulations, which exhibit inter-model inconsistency both in terms of regional ENSO climatology and responses to external forcing (Diffenbaugh et al., 2006; Harrison et al., 2003, 2014; Schmidt et al., 2014; Shin et al., 2006). Investigations of paleoclimate change in ENSO sensitive regions expand our 
temporal perspective on terrestrial climate responses to internal and external forcing and provide 94 a baseline for evaluating climate model hindcasts.

The oxygen isotopic composition of authigenic carbonate minerals (i.e., calcite and aragonite) in lacustrine sediments provides paleo-hydroclimate information on a wide range of timescales (from inter-annual to millennial) and therefore can be used to assess Holocene climate variability (Leng and Marshall, 2004; Talbot and Kelts, 1990; Talbot, 1990). This proxy is particularly informative as a drought/pluvial indicator in lake systems where the lake hydrologic budget is strongly influenced by shifts in precipitation-evaporation balance, and for which evaporation is a substantial component of total water loss (i.e., evaporation + outseepage) (Gat, 1995; Jones and Imbers, 2010; Shapley et al., 2008; Steinman and Abbott, 2013; Steinman et al., 2010a, 2010b). Most closed-basin lakes possess these traits and when located in a catchment with calcareous substrate often precipitate carbonate minerals from the water column (Kelts and Hsu, 1978; Koschel, 1997; Shapley et al., 2005), providing an archive of lake water isotope variability in response to climate driven changes in hydrologic balance. In contrast, open-basin lakes are not substantially influenced by evaporation and instead have a water isotopic composition that is controlled by that of through-flowing, meteoric water. Carbonate mineral $\left(\mathrm{CaCO}_{3}\right)$ oxygen isotope records from open-basin lakes can therefore provide information on past changes in the isotopic composition of precipitation, which complements the paleoclimate perspective obtained from closed-basin sediment oxygen isotope records.

Given the many factors that influence lake water isotopic composition (e.g., climate variations, lake morphometry, and the groundwater through-flow rate), qualitative attempts to interpret sediment core oxygen isotope records may inadequately characterize lake responses to climate change (Jones et al., 2005; Leng and Marshall, 2004; Steinman and Abbott, 2013; Steinman et al., 2013, 2010b). To address this issue, lake hydrologic and isotope mass balance models can be used to provide a framework for interpretation that quantitatively accounts for the many influences on lake hydrology and isotope dynamics. Such models provide a robust approach to interpreting lake sediment isotope records and have been used to provide insight into potential climate states capable of producing measured sediment core geochemical values and inferred past lake levels (Anderson et al., 2007; Benson and Paillet, 2002; Benson et al., 1996; Jones and Imbers, 2010; Jones et al., 2007, 2005; Li and Morrill, 2013; Morrill et al., 2006; 
123 Phillips et al., 1994, 1986; Rowe and Dunbar, 2004; Shapley et al., 2008; Stansell et al., 2012;

124 Steinman et al., 2013, 2012; Vassiljev, 1998a).

125 We present lake sediment oxygen isotope $\left(\delta^{18} \mathrm{O}\right)$ records of past precipitation-evaporation

126 balance from Cleland Lake (closed-basin; southeastern British Columbia), Paradise Lake

127 (closed-basin; central British Columbia) and Lime Lake (open-basin; eastern Washington) that

128 span the last $\sim 9,000$ years before present ( $\mathrm{yr}$ BP) and provide insight into western North

129 American climate system responses to ocean-atmosphere forcing on inter-annual to millennial

130 timescales. To reconstruct hydroclimate variability at a high temporal resolution, we analyzed

131 the isotopic composition of 2,246 samples collected at $\sim 1 \mathrm{~mm}$ resolution from the Cleland Lake

132 sediment cores, and 651 samples (combined) from the Paradise and Lime lake cores. We support

133 our interpretation of these records using sensitivity simulations conducted with a lake hydrologic

134 and isotope mass balance model (based on that of Steinman et al., 2010b). The objective of the

135 mass-balance model simulations is to determine the long-term hydrologic and isotopic sensitivity

136 of Cleland and Paradise to seasonal temperature and precipitation changes. These analyses

137 provide insight into the evolution of middle to late Holocene hydroclimate variability in the

138 Pacific Northwest as well as variability in the constraining internal and external forcing

139 mechanisms. We then compare the lake isotope series to other records of hydroclimatic change

140 from the greater Pacific Northwest region (which we define as British Columbia, eastern

141 Washington and Oregon, northern Idaho, and western Montana) as well as ocean sediment, coral,

142 and lake sediment based proxies of Holocene variability in synoptic climate modes (such as

143 ENSO and the NAM). This comparison allows us to form conclusions on how changes in the

144 Northern Hemisphere ocean-atmosphere system affected Holocene hydroclimate in the Pacific

145 Northwest. Lastly, we analyze results from global climate model (GCM) simulations of mid-

146 Holocene $(6,000 \mathrm{yr}$ BP) climate in order to investigate the physical plausibility of our

147 paleoclimate interpretations. Results from the climate model analysis provide perspective on

148 how ocean-atmosphere responses to orbital forcing influenced climate in western North America

149 during the mid-Holocene, as well as on inter-model heterogeneity in reconstructing paleoclimatic

150 conditions.

\section{Materials and Methods}




\subsection{Setting}

Climate in the greater Pacific Northwest region is influenced by interactions between Pacific ocean-atmosphere variability associated with the El Niño Southern Oscillation (ENSO) (Brown and Comrie, 2004; Cayan et al., 1999, 1998; Dettinger et al., 1998; McCabe and Dettinger, 2002, 1999; McCabe et al., 2008, 2004; Steinman et al., 2014; Wise, 2010) and the NAM (McAfee and Russell, 2008; Wallace and Thompson, 2002; Wang et al., 2006), which affects atmospheric pressure gradients on a hemispheric scale. A positive NAM is characterized by a greater pressure difference between the extra-tropical high- and low-pressure centers and a stronger, more zonal westerly jet stream. When ENSO is in a negative (i.e., La Niña) phase and NAM is positive, wetter cold season conditions (October-March) typically occur in the Pacific Northwest; whereas drier conditions occur during the opposite set of conditions (Fig. 1).

Cleland Lake $\left(50.830^{\circ} \mathrm{N}, 116.390^{\circ} \mathrm{W}, 1,126 \mathrm{~m}\right.$ asl $)$ is an alkaline, surficially closedbasin system located on an elevated terrace west of the Columbia River (Fig. 1). Precipitation amounts recorded at the Brisco weather station (from AD 1986-2003) (50.82 $\mathrm{N}, 116.26^{\circ} \mathrm{W}$, $823 \mathrm{~m}$ asl) (Climate ID: 1171020; Meteorological Service of Canada) indicate that precipitation is somewhat seasonal, with about $35 \%$ and $24 \%$ of total annual precipitation occurring during the early summer (May-June) and late fall/early winter (November-January), respectively (Fig. S1). Mean monthly precipitation $\delta^{18} \mathrm{O}$ values vary by as much as $10 \%$ o throughout the year (Table S1). The topography is characterized by hills and valleys overlain by glacial till dissected by rivers and streams as well as numerous small alkaline lakes that formed after the last deglaciation. Cleland Lake has a surface area of $0.28 \mathrm{~km}^{2}$, an estimated watershed area of 2.02 $\mathrm{km}^{2}$ (Fig. S2), and contains extensive littoral carbonate platforms surrounding a deep anoxic basin (maximum depth of $\sim 32 \mathrm{~m}$ ) (Mihindukulasooriya et al., 2015). During the observational period (AD 2009-2014), the surface water of Cleland Lake was $\sim 2 \mathrm{~m}$ below the surficial overflow level. The catchment contains second-growth forests that include Pinus ponderosa (ponderosa pine), Pseudotsuga menziesii (Douglas fir), Picea (spruce) and Betula (birch) (Klenner et al., 2008).

Paradise Lake $\left(54.685^{\circ} \mathrm{N}, 122.617^{\circ} \mathrm{W}, 733 \mathrm{~m}\right.$ asl) is an alkaline, surficially closed-basin system located in central British Columbia $\sim 600 \mathrm{~km}$ northwest of Cleland Lake (Fig. 1). Precipitation amounts recorded at the Prince George weather station (from AD 1984-2004) 
$\left(54.05^{\circ} \mathrm{N}, 122.74^{\circ} \mathrm{W}, 762 \mathrm{~m}\right.$ asl) (Climate ID: 1096458; Meteorological Service of Canada) indicate that February-May are the driest months and that September-January and June are the wettest months (Fig. S1; Table S1). Mean monthly precipitation $\delta^{18} \mathrm{O}$ values vary by as much as $10 \%$ throughout the year. The topography is similar to that of Cleland Lake, with numerous hills and valleys dissected by small, seasonally ephemeral streams and larger rivers, and lakes that formed after the last deglaciation. Paradise Lake has a surface area of $0.09 \mathrm{~km}^{2}$, an estimated watershed area of $1.70 \mathrm{~km}^{2}$ (Fig. S3), and contains an extensive littoral carbonate platform along the southeastern shore. A series of sediment cores collected along the long axis of the lake revealed a decrease in carbonate mineral content with increasing depth (maximum depth of $\sim 21$ m). The catchment contains second-growth forests including, Picea (spruce), Betula (birch), and Populus (Aspen).

Lime Lake $\left(48.874^{\circ} \mathrm{N}, 117.338^{\circ} \mathrm{W}, 781 \mathrm{~m}\right.$ asl) is an alkaline, open-basin system located in northeastern Washington $\sim 230 \mathrm{~km}$ south/southwest of Cleland Lake. Precipitation amounts recorded at the Metaline Falls weather station (AD 1909-1965) (48.87 N, 117.37 W, $643 \mathrm{~m}$ asl) (Station: 455317; Western Regional Climate Center) indicate that summers (JulySeptember) are relatively dry and that the cold season (October-March), as well as late spring (May-June), are wet (Fig. S1). Mean monthly precipitation $\delta^{18} \mathrm{O}$ values vary by as much as $8 \%$ throughout the year. The lake surface area is $0.04 \mathrm{~km}^{2}$, and the watershed area is $\sim 1.06 \mathrm{~km}^{2}$ (Fig. $\mathrm{S} 4$ ). The lake basin is steep sided with a flat bottom (maximum depth of $\sim 15.5 \mathrm{~m}$ near the southwestern shoreline). Lime Lake is situated on the edge of a terrace of the Okanogan River with a surrounding topography characterized by hummocky, post-glacial terrain. The catchment forest predominantly consists of Pseudotsuga menziesii (Douglas fir), Pinus ponderosa (ponderosa pine), and Betula (birch).

\subsection{Field sampling and analysis}

In May 2009, we recovered a $249 \mathrm{~cm}$-long sediment profile from Cleland Lake in a depth of $20.2 \mathrm{~m}$ (in anoxic bottom water) (Mihindukulasooriya et al., 2015) using a $6.7 \mathrm{~cm}$ diameter polycarbonate tube attached to a rod driven piston corer (Core B-09). In July 2009, we collected a $50 \mathrm{~cm}$ freeze core of surface sediment (Core C-09) from Cleland Lake using a hollow steel wedge filled with an ethanol-dry ice slurry. Both of these cores were stratigraphically correlated 
using the Mt. St. Helens Wn tephra (Mullineaux, 1986; Yamaguchi, 1985) (Supplemental Information). In October 2006 and May 2010 we used a $6.7 \mathrm{~cm}$ diameter polycarbonate tube attached to a rod driven piston corer and a modified $(5 \mathrm{~cm})$ Livingstone piston corer to collect sediment cores from Lime Lake (Core B-06 / Core A-06 / 350 cm) and Paradise Lake (Core A10 / Core B-10 / 250 cm) in water depths of $2 \mathrm{~m}$ and $15.5 \mathrm{~m}$, respectively. Surface sediments were sampled in the field at $0.5 \mathrm{~cm}$ (Lime Lake) and $0.25 \mathrm{~cm}$ (Paradise Lake) intervals by upward extrusion into a tray fitted to the top of the core barrel and transferred to sterile plastic bags.

Surface water samples for oxygen and hydrogen isotope analyses were intermittently collected from lakes and streams in the vicinity of Cleland Lake during the spring and/or summer from AD 2009-2014 (Fig. 2). Streams and lakes in the Lime Lake region were sampled from AD 2006-2013 and in the Paradise Lake region during May 2010 and August 2012. Water samples were collected in $30 \mathrm{~mL}$ polyethylene bottles after rinsing three times with sample water and then filling and capping the bottle underwater. All samples were stored in cool $\left(\sim 4{ }^{\circ} \mathrm{C}\right)$, dark conditions until analysis. Isotopic ratios of the water samples were measured at the University of Arizona Environmental Isotope Laboratory on a gas-source isotope ratio mass spectrometer (Finnigan Delta S). Hydrogen isotope analyses were conducted by reacting samples at $750^{\circ} \mathrm{C}$ with $\mathrm{Cr}$ metal using a Finnigan H/Device coupled to the mass spectrometer. Oxygen isotope analyses were conducted by equilibrating samples with $\mathrm{CO}_{2}$ gas at approximately $15^{\circ} \mathrm{C}$ in an automated equilibration device coupled to the mass spectrometer. All water isotope results are reported in standard delta notation relative to Vienna Standard Mean Ocean Water (VSMOW). Precision $(1 \sigma)$ is 0.9 per mil $(\%)$ or better for $\delta \mathrm{D}$ and $0.08 \%$ or better for $\delta^{18} \mathrm{O}$ on the basis of repeated measurement of internal standards. Sulfuric acidt itrat ions were conduct ed on sa mpl es of surface water from each lake using a Hach ${ }^{\circledR}$ Dig it al Titrator to determine total dissolved bicar bonate and car bonate concentrations (i.e., alkal inity).

\subsection{Geochronology}

The age profiles of the surface sediments were determined using ${ }^{210} \mathrm{~Pb}$ and ${ }^{137} \mathrm{Cs}$ dating methods (Tables S2-S4), while the chronology of deeper sediments was constrained using radiocarbon and tephrochronology (Fig. 3; Tables S5-S7). Radioisotope $\left({ }^{210} \mathrm{~Pb}\right.$ and $\left.{ }^{214} \mathrm{~Pb}\right)$ 
activities were measured by direct gamma counting for 48 hours using a high-purity, broadenergy germanium detector (Canberra BE-3825) at the University of Pittsburgh following a three week equilibration period in airtight petri dishes. Radioisotope activities were interpreted using the constant rate of supply (CRS) model (Appleby and Oldfield, 1978; Binford, 1990; Lima et al., 2005). Sediment sub-samples for radiocarbon dating were disaggregated with $7 \% \mathrm{H}_{2} \mathrm{O}_{2}$ and sieved through a $125-\mu \mathrm{m}$ screen to isolate terrestrial macrofossils, which were collected using a small brush under a binocular microscope and pretreated using a standard acid-base-acid procedure (Abbott and Stafford Jr., 1996). Radiocarbon samples were measured at the W. M. Keck Carbon Cycle Accelerator Mass Spectrometry Laboratory at the University of California Irvine. Mount Saint Helens Wn (Yamaguchi, 1985) and Mazama (Hallett et al., 1997; Zdanowicz et al., 1999) tephra layers were identified using microprobe analysis (Table S8).

\section{Classical Age Modeling (CLAM2.2) software for R and the IntCAL13 (Reimer, 2013)} calibration curve were used to produce age models based on linear interpolation between dates and to generate $95 \%$ confidence intervals for the interpolated ages (Blaauw, 2010). Several dates were considered outliers by the CLAM software and were omitted from the age models of each core. In the case of Cleland Lake, two dates were omitted: one from $38 \mathrm{~cm}$ that was inconsistent with the age of the Mount Saint Helens W (MSH-W) tephra at $44 \mathrm{~cm}$ and one from $215 \mathrm{~cm}$ that had a large uncertainty range. For Paradise Lake, one date at $93 \mathrm{~cm}$ was omitted because it produced an age-depth reversal, and two were omitted $(269.5 \mathrm{~cm}, 327.5 \mathrm{~cm})$ because of their large uncertainty range and inconsistency with other nearby dates with much smaller uncertainty ranges. Four dates were omitted from the Lime Lake age model: one at $43 \mathrm{~cm}$ because of inconsistency with the MSH-W tephra, and three $(112.3 \mathrm{~cm}, 137.3 \mathrm{~cm}, 173.6 \mathrm{~cm})$ that produced either reversals or large changes in the sedimentation rate that were not accompanied by a commensurate shift in the sedimentology or sediment geochemistry.

\subsection{Sediment core sampling and analysis}

At the University of Pittsburgh, the Cleland Lake sediment freeze core was sampled using a razor blade at an average resolution of $\sim 1 \mathrm{~mm} /$ sample with locations marked on digital photographs of the core. The Cleland Lake piston core was sampled $(\mathrm{N}=2,246$ including the freeze core samples) along the plane of sediment laminae using a custom made slicing 
278 mechanism to maximize the temporal resolution. The Paradise Lake $(\mathrm{N}=379)$ and uppermost

279 (Surface Core D-06) Lime Lake (N=272) cores were also sampled along the plane of sediment

280 laminae using the core slicing mechanism at 1-2 mm intervals. The lower sections of the Lime

281 Lake core were sampled at $\sim 5 \mathrm{~cm}$ intervals using a $1 \mathrm{cc}$ sampler. Samples were prepared for

282 isotopic analysis by disaggregating in $7 \% \mathrm{H}_{2} \mathrm{O}_{2}$ for $\sim 24$ hours, wet sieving through a $63 \mu \mathrm{m}$

283 screen to remove the coarse fraction (and thereby isolate the fine grain size), and treating with 3

$284 \% \mathrm{NaClO}$ for 6 hours to remove organic matter. The treated fine fraction was then rinsed 3 times

285 using deionized water, frozen, lyophilized, homogenized using a mortar and pestle, and sealed in 286 labeled glass vials.

287 Isotope analyses of the Cleland Lake samples were conducted at The University of

288 Florida. The Lime Lake and Paradise Lake isotope analyses were conducted at the University of 289 Arizona. In both cases samples were reacted in orthophosphoric acid at $70^{\circ} \mathrm{C}$ using a Finnigan-

290 MAT Kiel III carbonate preparation device. The oxygen and carbon isotopic composition of 291 evolved $\mathrm{CO}_{2}$ gas was measured with a Finnigan-MAT 252 mass spectrometer. All carbonate 292 isotope results are reported in standard delta notation relative to Vienna Pee Dee Belemnite 293 (VPDB). Analytical precision at the University of Florida, based on repeated measurements of 294 NBS-19 carbonate standard materials $(\mathrm{N}=459)$, was $0.04 \%$ for $\delta^{13} \mathrm{C}$ and $0.08 \%$ for $\delta^{18} \mathrm{O}$.

295 Analytical precision at the University of Arizona, based on repeated measurements of NBS-18 and NBS-19, was better than $0.1 \%$ for $\delta^{18} \mathrm{O}$ and $0.08 \%$ for $\delta^{13} \mathrm{C}$.

Mineral phase characterization by X-ray diffractometry was completed at the University

299 Diffractometer over a $2 \theta$ range of $10^{\circ}$ to $80^{\circ}$. X-ray diffraction results indicate that calcite is the 300 only detectable carbonate mineral in the fine-grained sediment at Paradise Lake and Lime Lake, 301 and that aragonite is the predominant carbonate mineral in the Cleland Lake sediment (i.e. a 302 small amount of calcite is likely present in some samples).

\subsection{Lake modeling overview}

Hydrologic and isotope mass balance models can be used to investigate lake sensitivity to 307 specific climate variables (Calder et al., 1995; Dinçer, 1968; Donovan et al., 2002; Gat, 1970; 308 Gibson et al., 2015, 1996; Hastenrath and Kutzbach, 1983; Hostetler and Benson, 1994; Jones 
and Imbers, 2010; Lyons et al., 2011; Morrill, 2004; Shanahan et al., 2007; Shapley et al., 2008; Steinman et al., 2010b; Tate et al., 2004; Troin et al., 2010; Vassiljev, 1998b; Zuber, 1983) and to develop a basis for the paleo-interpretation of sediment geochemical records (Anderson et al., 2007; Benson and Paillet, 2002; Hoelzmann et al., 2000; Jones et al., 2007; Morrill et al., 2006; Phillips et al., 1994; Roberts et al., 2008; Steinman et al., 2012; Vallet-Coulomb et al., 2006). Here we apply a lake hydrologic and isotope mass balance model to characterize the isotopic responses of Cleland Lake and Paradise Lake water and authigenic carbonate to changes in precipitation and temperature. These hydroclimatic variables, as well as catchment parameters and basin morphology, control water balance and residence time in closed-basin lakes and therefore determine lake geochemical responses to climate dynamics. We did not apply the model to Lime Lake because (in accordance with our study design) it is a hydrologically open system that is largely insensitive to changes in precipitation-evaporation balance, with water and sediment isotope values that reflect variability in the isotopic composition of meteoric water (i.e. precipitation) (Fig. 2). We use these model simulations as a framework for the interpretation of the Cleland Lake and Paradise Lake sediment $\delta^{18} \mathrm{O}$ records.

\subsection{Lake model structure}

The hydrologic and isotope mass balance model is based on the lake-catchment model of (Steinman et al., 2010b) and is defined by a system of four ordinary differential equations compiled using STELLA ${ }^{\circledR}$ (isee systems ${ }^{\mathrm{TM}}$ ) software (Supplemental Information; Table S9). The model consists of two water reservoirs (one representing the lake and one for the catchment/groundwater) that track the volumetric fluxes between them, and calculates the mass balance through time for the lake reservoir by balancing the volumetric addition of precipitation over the lake area and inflow from the catchment/groundwater reservoir against the loss of lake water by evaporation and outseepage through the lakebed. Mass balance for the catchment/groundwater reservoir is determined by the addition of water through a parameterized precipitation input flux and the subtraction of water flowing from the catchment into the lake. All model simulations were conducted on a monthly time step (eight iterations per month) using the fourth-order Runge-Kutta numerical integration method. To adapt the model of Steinman et al. (2010b) to Cleland Lake and Paradise Lake, we made several adjustments, including 1) the 
application of a simplified lake water input algorithm that simulates groundwater flow and catchment runoff into the lake, 2) the development of a simplified lake hypsography algorithm that assumes a conic lake shape and requires observations of maximum lake depth and surface area as inputs, and 3) the use of a lake outseepage sub-model based on the method of Steinman et al. (2012), wherein lake bed outseepage varies exponentially as a function of offshore distance. May-July average values are used for model estimates of annual carbonate mineral isotope values. This assumption is based on observational and theoretical evidence that carbonate mineral precipitation principally occurs in the late spring/early summer due to the effect of primary productivity on $\mathrm{pH}$, warmer water temperatures, and increases in alkalinity and $\mathrm{Ca}^{2+}$ ion concentrations from evaporative enrichment (see Section 3.4, below, for references and additional discussion) (Steinman et al., 2013). The model presented here therefore provides an approximation of the general hydrology and isotope dynamics of a small, non-stratified, closedbasin lake that precipitates carbonate minerals in the warm season.

\subsection{Lake model inputs}

Model simulations utilized monthly weather data derived from gridded observational data products and climate model reanalysis experiments (Table S1). Local weather station data averages were not applied because they spanned too short a time period to provide robust estimates of local climatology, and they may not be regionally representative given localized heterogeneity in climate. Average monthly precipitation $(P)$ and temperature $(T)$ were determined using the University of Delaware terrestrial precipitation and temperature series $(0.5$ degree spatial resolution) (AD 1900-2010) (version 3.0.1). Average monthly incoming solar insolation $\left(R_{S}\right)$, relative humidity $(R H)$ and wind speed $(W S)$ were determined using data from the NOAA $20^{\text {th }}$ Century Reanalysis Project (v2) (AD 1871-2010) (Compo et al., 2011). Extraterrestrial solar insolation $\left(R_{a}\right)$ is calculated in the model based on latitude and Julian day number using equations described by Valiantzas (2006). Average lake water temperature $\left(T_{w}\right)$ is estimated to be $+2.5^{\circ} \mathrm{C}$ relative to air temperature based on measurements of other, similar lake systems (Steinman et al., 2010b). Monthly $\delta^{18} \mathrm{O}$ and $\delta \mathrm{D}$ values of precipitation were approximated using interpolated values (waterisotopes.org) (Bowen and Revenaugh, 2003) and were not adjusted during the temperature sensitivity tests. Hence the temperature effects on the 
extent of rainout and water vapor fractionation via Rayleigh distillation (Rozanski et al., 1992) are not considered in the simulations. Initial lake surface area and maximum depth were estimated using bathymetric data, satellite imagery and topographic maps (Figs. S2-S4).

\subsection{Lake model calibration}

In the first series of model simulations the model calibration constants $\left(C_{C P}, C_{I N}\right.$, and $\left.C_{E X P}\right)$ were iteratively adjusted to balance the model at lake depths and $\delta^{18} \mathrm{O}$ values consistent with observations (similar to the methodology of (Steinman et al., 2010b)) (Fig. S5). The catchment precipitation constant $\left(C_{C P}\right)$ determines the flux of water as a function of precipitation minus potential evapotranspiration $(P-P E T)$ into the catchment/groundwater reservoir $\left(R E S_{C G}\right)$. Steady-state simulations were conducted for both Cleland Lake and Paradise Lake in which $C_{C P}$ was adjusted downward from a large initial value (larger values produce greater catchment water influx to the lake), while simultaneously decreasing the outseepage function power $\left(C_{E X P}\right)$ (larger values produce increased through-flow), until the lake depth and water $\delta^{18} \mathrm{O}$ values were similar to observations. After balancing the model at steady state, the catchment inflow delay constant $\left(C_{I N}\right)$ was assigned a value of 0.1 for both lakes, which reduced inflow to the lake $\left(F_{I N}\right)$ values to $10 \%$ of $R E S_{C G}$, in order to approximate precipitation transit times through the catchment via surface and groundwater pathways. With this calibration the model simulations produced a realistic pattern of seasonal lake water $\delta^{18} \mathrm{O}$ variations, with minimum values in May, maximum values in October, and mean May-July values of -6.4 \%o and -15.9 \%o for Cleland and Paradise, respectively, (Fig. S5) which are very similar to measured water isotope values (Fig. 2, inset). In addition, model average May-July aragonite and calcite $\delta^{18} \mathrm{O}$ values $(\sim 6.1 \%$ for Cleland, $\sim 15.4$ $\%$ for Paradise) are similar to measured $20^{\text {th }}$ century values in the sediment cores, reinforcing the efficacy of the model in simulating Cleland Lake and Paradise Lake water and sediment isotope dynamics.

\subsection{Lake model sensitivity to climate variables}

The objective of this set of experiments was to determine the long-term hydrologic and isotopic sensitivity of Cleland Lake and Paradise Lake to temperature and precipitation changes. 
Each set of sensitivity tests spanned over 2,000 model months (167 years) and used modern catchment parameters and average, monthly climate data as model inputs. In the $1,000^{\text {th }}$ month, the tested climate variable was either increased or decreased by a constant amount and maintained until the end of the test. The effect of changes in both seasonal and annual climate was investigated by varying warm (April-September) and cold (October-March) season temperature and precipitation on a monthly basis, as well as annual mean/total values over a two standard deviation range constrained by observational data. For example, in the annual precipitation sensitivity tests, precipitation for each month was changed by $\pm 12 \%$; whereas in the cold season precipitation tests, values in the months of October-March were changed by \pm 12 $\%$. The values chosen for the sensitivity experiments $\left( \pm 0.6^{\circ} \mathrm{C}\right.$ for temperature and $\pm 12 \%$ for precipitation) were determined by calculating the mean standard deviation of the 20 year moving average of the annual, cold and warm season temperature and precipitation series for the Cleland Lake location and doubling this value for the experiments. For example, the mean of standard deviations of the cold, warm, and annual 20 year moving averages is $\sim 0.3{ }^{\circ} \mathrm{C}$, so two times this value (i.e., $\pm 0.6^{\circ} \mathrm{C}$ ) was used in the temperature sensitivity tests. This method for calculating the limits of the sensitivity experiments utilizes observed multidecadal variability in climate to provide constraint in the simulations rather than arbitrarily chosen values. To ensure consistency in the study design between sites, the same climate forcing values were applied to the Paradise Lake model. Late spring/early summer average (May-July) $\delta^{18} \mathrm{O}$ values were assessed to account for the timing of carbonate mineral precipitation in response to algal blooms, evaporative enrichment, and water temperature increases.

\subsection{Significance of middle and late Holocene proxy value differences}

We conducted one tailed t-tests to assess the statistical significance of the differences in average proxy record values from the middle and late Holocene (Table 1). The records were interpolated at a spacing equivalent to their approximate average time resolution. To account for redness in the data we adjusted the degrees of freedom by dividing the number of data points from each time period by the decorrelation time $(1+\rho) /(1-\rho)$, where $\rho$ is the lag-1 autocorrelation. 
434

To provide support for interpretations of the lake $\delta^{18} \mathrm{O}$ records, we analyzed output from two mid-Holocene (6,000 yr BP) simulations conducted as part of the Paleoclimate Model Intercomparison Project Phase 3 (PMIP3) (Braconnot et al., 2012). Modeled precipitation minus evaporation balance $(\mathrm{mm} /$ day), surface pressure $(\mathrm{Pa})$, and surface wind speed $(\mathrm{m} / \mathrm{s})$ anomalies were determined for each model grid cell by calculating the difference between monthly climatology values in the mid-Holocene and preindustrial control simulations from the Coupled Model Intercomparison Project Phase 5 (CMIP5), the latter of which are forced with boundary conditions from the year AD 1850 (Taylor et al., 2012). The models are the Max Planck Institute Earth System Model version P (MPI-ESM-P) (Jungclaus et al., 2013) and the Meteorological Research Institute Coupled Global Climate Model version 3 (MRI-CGCM3) (Yukimoto et al., 2012). MPI-ESM is a comprehensive Earth System Model that includes components for the ocean, atmosphere, land surface, aerosols, and sea ice that are coupled through the exchange of energy, momentum, water and important trace gases such as carbon dioxide. MPI-ESM-P is the low resolution (LR) version (1.875 ${ }^{\circ}$ spatial resolution) of MPI-ESM configured for paleoclimate simulations and does not include a dynamic vegetation sub-model. MRI-CGCM3 (1.125 spatial resolution) is an ocean-ice, atmosphere, land, and aerosol general circulation model. The MPIESM-P mid-Holocene simulations spanned 100 years with a control simulation length of 1000 years. The MRI-CGCM3 mid-Holocene and control experiments spanned 100 and 500 years, respectively. The orbital parameters of the mid-Holocene experiments were consistent with Earth's configuration at $6000 \mathrm{yr}$ BP, including adjustments to obliquity, eccentricity, and perihelion (precession). Atmospheric methane concentrations were adjusted to a mid-Holocene value of $760 \mathrm{ppb}$, an increase relative to the preindustrial control simulation value of $650 \mathrm{ppb}$. All other model boundary conditions including the date of the vernal equinox (March $21^{\text {st }}$ at noon), other trace gas concentrations $\left(\mathrm{CO}_{2}, \mathrm{~N}_{2} \mathrm{O}, \mathrm{CFC}\right.$, and $\left.\mathrm{O}_{3}\right)$, aerosols, the solar constant $\left(1,365 \mathrm{~W} / \mathrm{m}^{2}\right)$, ice sheets, and topography and coastlines were identical to those of the preindustrial control experiments.

\section{Results and Discussion}




\subsection{Sources of water and sediment $\delta^{18} \mathrm{O}$ variability}

Many climatic variables including temperature, humidity, precipitation amounts, seasonality and their effects on the isotopic composition of precipitation influence lake water and authigenic $\mathrm{CaCO}_{3} \delta^{18} \mathrm{O}$ values, leading to complex lake responses to climate change (Benson and Paillet, 2002; Gat, 1995; Gonfiantini, 1986; Hostetler and Benson, 1994; Jones and Imbers, 2010; Shapley et al., 2008; Steinman et al., 2013, 2010b). In general, the ${ }^{18} \mathrm{O}$ (and deuterium) content of lake water increases when conditions are drier (and lake levels are lower) due to preferential removal of the lighter ${ }^{16} \mathrm{O}$ isotope from the water by evaporation, and reduced inflow of ${ }^{18} \mathrm{O}$ depleted meteoric water (Craig and Gordon, 1965; Dinçer, 1968; Gat, 1981; Gonfiantini, 1986; Leng and Marshall, 2004). When conditions are wetter (and lake levels are higher and/or overflow volume is greater) the opposite effect occurs. More specifically, in closed-basin lakes that lose water almost entirely through evaporation (and very little through outseepage or overflow), changes in temperature and relative humidity (which control evaporation rates and equilibrium and kinetic fractionation) are the strongest influences on lake water and sediment $\delta^{18} \mathrm{O}$ values on longer timescales (i.e., decadal to centennial) (Gat, 1981; Gibson et al., 2002; Horita and Wesolowski, 1994; Merlivat and Jouzel, 1979; Shapley et al., 2008; Steinman and Abbott, 2013; Steinman et al., 2010b). Lakes with this type of hydrology will exhibit a large transient isotopic response to mean state shifts in precipitation-evaporation balance, but will not exhibit a corresponding mean state isotopic shift because the proportion of water lost through evaporation cannot substantially change. Conversely, in open-basin lakes that lose the vast majority of water through groundwater seepage or overflow, the isotopic composition of meteoric water is the primary influence on lake oxygen isotope content, with secondary control by temperature and relative humidity (Leng and Marshall, 2004). This occurs because changes in precipitation-evaporation balance do not strongly affect the proportion of water lost through fractionating versus non-fractionating outflow pathways in lakes that remain open even when climate becomes substantially drier. Notably, lakes that fall in between these two end members (such as Paradise and Cleland, which model simulations suggest lose $\sim 12 \%$ and $\sim 80 \%$ of water through evaporation, respectively) will exhibit a strong mean state isotopic response to changes in hydrologic balance driven by long-term changes in precipitation amount (Steinman and Abbott, 2013; Steinman et al., 2010b). This occurs because such lakes are subject to large 
changes in the proportion of water lost through evaporation versus outseepage and overflow in response to hydrologic forcing.

Closed-basin lakes such as Cleland and Paradise often exhibit considerable intra- and inter-annual variability in response to climate and are in a constant state of hydrologic and isotopic disequilibrium (Gibson, 2002; Gibson et al., 2002; Steinman et al., 2013, 2010a). In these settings, high frequency (e.g., sub-decadal) variability in the isotopic composition of lake sediment is primarily controlled by inter-annual climate variations and is less influenced by low frequency (e.g., decadal to centennial) climate variability. Over longer timescales, high frequency responses are averaged to produce isotopic values that are primarily a function of mean state climate conditions (i.e., the long-term average) and to a lesser extent shorter timescale climate variability, which affect lake hydrologic balance through non-linear catchment runoff responses to precipitation forcing (Steinman et al., 2012, 2010a).

Field observations and measurements of lake water level and isotopic values (Fig. 2) provide insight into intra- and inter-annual lake responses to seasonality and short timescale climate variability. Over a five-year observational period (AD 2009-2014) Cleland Lake exhibited substantial lake-level and isotopic changes. The lake water is alkaline $(\sim 660 \mathrm{mg} / \mathrm{l})$ with surface water $\delta^{18} \mathrm{O}$ values that averaged $-6.1 \%(\mathrm{~N}=7)$. The Cleland Lake level dropped visibly between July 2009 and August 2010 during which the water isotope values increased by $1.3 \%$ (Fig. 2, inset); lake level increased by $1 \mathrm{~m}$ between August 2010 and August 2011 while $\delta^{18} \mathrm{O}$ values decreased by $1.7 \%$. Over a six-year observational period (AD 2006-2012) Lime Lake surface water $\delta^{18} \mathrm{O}$ values averaged $-15.1 \%$ o $(\mathrm{N}=10)$ and lake level did not appreciably change. Paradise lake was sampled only twice due to its relatively remote location, and the surface water $\delta^{18} \mathrm{O}$ values averaged $-15.6 \%$. Both Lime Lake $(\sim 210 \mathrm{mg} / \mathrm{L})$ and Paradise Lake $(\sim 100 \mathrm{mg} / \mathrm{L})$ are alkaline.

Cleland and Paradise water isotope values plot along the local evaporation line (Fig. 2), indicating substantial water losses through evaporation relative to non-fractionating outflow pathways (i.e., overflow and outseepage through the lake bed), further suggesting that Cleland Lake and Paradise Lake are isotopically and hydrologically sensitive to shifts in precipitationevaporation balance. Conversely, Lime Lake water isotope values plot at the intersection of the local evaporation line and the meteoric water line, indicating that changes in precipitationevaporation balance are not a strong influence on Lime Lake hydrology and isotope dynamics. 
526 This observational dataset forms the basis for our interpretation that the Cleland Lake and

527 Paradise Lake oxygen isotope records principally reflect past changes in precipitation-

528 evaporation balance, and that the Lime Lake record provides information on variability in the

529 isotopic composition of precipitation.

530

\subsection{Age models}

532

In the surface sediments of each lake the maximum ${ }^{137} \mathrm{Cs}$ activity (resulting from the radionuclide fallout peak in AD 1963) is generally concomitant (i.e., either within, or nearly within, the $2 \sigma$ uncertainty range) with the ${ }^{210} \mathrm{~Pb}$ defined age (Fig. 3 inset; Tables S2-S4). At all three lakes, long-term sedimentation rates were generally steady throughout the middle to late Holocene and averaged $\sim 0.3 \mathrm{~mm} / \mathrm{yr}$ for Cleland and Paradise and $\sim 0.4 \mathrm{~mm} / \mathrm{yr}$ for Lime, with an apparent increase during the historical period that is largely a result of greater sediment compaction at depth.

\subsection{Lake model sensitivity simulations}

To assess Cleland and Paradise lake sensitivity to longer timescale (i.e multidecadal to cenntennial) climate change we conducted steady-state lake model simulations in which climate variables in different seasons were changed by a fixed amount. We did not model Lime Lake because open-basin lake water isotope values reflect that of meteoric water and are not substantially influenced by evaporation. In separate simulations, cold season, warm season, and

548 annual temperature and preciptiation were changed by $\pm 0.6^{\circ} \mathrm{C}$ and $\pm 12 \%$, respectively. This ensemble structure allows direct comparison of lake responses to climate forcing in different seasons.

Changes in atmospheric temperature influence lake hydrologic and isotopic balance by altering evaporative flux from the lake surface (Valiantzas, 2006), catchment evapotranspiration

554 the liquid-vapor equilibrium fractionation factor for evaporating water (Horita and Wesolowski, 555 1994). At both Cleland and Paradise, model simulations of cold season changes in temperature 556 produced steady-state (May-July average) isotopic offsets in both water and $\mathrm{CaCO}_{3}$ of less than 
$\pm 0.06 \%$, and were directionally consistent (Fig. S6). Warm season temperature changes

558 produced mean isotopic offsets that were similar in magnitude (less than $\pm 0.08 \%$ ), but directionally opposite that of the winter values due to the influence of water temperature changes on the $\mathrm{CaCO}_{3}$-water equilibrium fraction factor (see equation 7 in Supplemental Information). When temperatures increase, for example, the $\mathrm{CaCO}_{3}$-water fractionation factor decreases (Kim and O'Neil, 1997; Kim et al., 2007), leading to an isotopic depletion of $\mathrm{CaCO}_{3}$ that is larger in magnitude than the isotopic enrichment resulting from higher evaporation rates and reduced catchment water influx to the lake. Annual atmospheric temperature changes of $\pm 0.6{ }^{\circ} \mathrm{C}$ resulted in average (May-July) water and $\mathrm{CaCO}_{3} \delta^{18} \mathrm{O}$ offsets of less than $\pm 0.12 \%$, suggesting that lake isotope dynamics are relatively insensitive to temperature changes.

The lake model simulation results demonstrate that Cleland and Paradise lake water and authigenic $\mathrm{CaCO}_{3} \delta^{18} \mathrm{O}$ values are highly sensitive to cold season precipitation amounts and the resulting influence on lake hydrology (Figs. 4,S6). In response to cold season precipitation changes of $\pm 12 \%$, Cleland and Paradise exhibited mean state water and $\mathrm{CaCO}_{3} \delta^{18} \mathrm{O}$ variations of less than $\pm 0.57 \%$ (Fig. S7 depicts corresponding depth changes). In contrast, warm season precipitation changes of $\pm 12 \%$ produced much smaller steady-state oxygen isotope variations of less than $0.04 \%$. For both lakes the isotopic responses to warm season precipitation variability were much lower in magnitude than the cold season responses due to the offsetting effects on lake water and sediment isotope values of changes in both the hydrologic balance and the isotopic composition of precipitation. For example, in the case of Paradise Lake an increase in warm season precipitation produced a slight increase in water and $\mathrm{CaCO}_{3} \delta^{18} \mathrm{O}$ values (rather than the expected decrease commonly associated with positive hydrologic balance anomalies) (and vice versa) due to the substantially more enriched $\delta^{18} \mathrm{O}$ values of warm season precipitation. Additionally, the much stronger response of lakes to changes in cold season precipitation (which has been identified in observational and modeling studies of other lakes (Steinman and Abbott, 2013; Steinman et al., 2012)) occurs in part because evapotranspiration rates are high enough in the warm season (even in years with relatively cool warm seasons) to prevent precipitation from saturating catchment soils and either surficially flowing into or entering the lake via groundwater.

Although not simulated here, relative humidity is an additional, potentially strong influence on water and $\mathrm{CaCO}_{3} \delta^{18} \mathrm{O}$ values through control of the kinetic isotopic separation and 
resulting effect on the oxygen isotope content of evaporating water (Araguás-Araguás et al., 2000; Craig and Gordon, 1965; Merlivat and Jouzel, 1979). Given that higher relative humidity values usually occur when conditions are wetter (e.g., precipitation amounts are greater), it is likely that a significant amount of variability in the Cleland and Paradise lake $\delta^{18} \mathrm{O}$ records can be explained by changes in relative humidity. For example, increases in summer precipitation would lead to increased relative humidity and a consequent decrease in evaporation rates and kinetic isotopic separation during evaporation, and vice versa. Under these conditions, relative humidity changes resulting from greater precipitation amounts would amplify the hydrologic and isotopic response of the lake to precipitation variability.

\subsection{Lake sediment $\delta^{18} \mathrm{O}$ and $\delta^{13} \mathrm{C}$ variability}

In lakes with high alkalinity and calcium ion concentrations, carbonate minerals will precipitate from the water column and remain preserved in the sediment in response to evaporative concentration of dissolved ions in the warmer months, as well as photosynthetically mediated increases in $\mathrm{pH}$ and consequent shifts in carbonate speciation toward the $\mathrm{CO}_{3}{ }^{2-}$ phase (Hodell et al., 1998; Kelts and Hsu, 1978; Koschel et al., 2011; Koschel, 1997; Raidt and Koschel, 1988; Sondi and Juracic, 2010; Thompson et al., 1997). The $\mathrm{CaCO}_{3}$ forms in equilibrium with the dissolved inorganic carbon (DIC) pool and oxygen in lake water, effectively 'recording' the water isotopic composition, with a secondary influence by lake water temperature on the calcite-water oxygen isotopic separation (Kim and O'Neil, 1997; Kim et al., 2007). As such, the isotopic composition of authigenic $\mathrm{CaCO}_{3}$ preserved in lake sediment provides an informative paleoclimate proxy for past changes in either hydrologic balance (in the case of closed-basin lakes) or the isotopic composition of precipitation (in the case of open-basin lakes) in response to hydroclimate variability (Benson and Paillet, 2002; Jones and Roberts, 2008; Leng and Marshall, 2004; Shapley et al., 2008; Steinman and Abbott, 2013; Steinman et al., 2010b; Talbot and Kelts, 1990; Talbot, 1990).

Covariance between oxygen and carbon isotope values in sedimentary carbonates can provide information about the degree of hydrologic closure of a lake system (Horton et al., 2016; $\mathrm{Li}$ and $\mathrm{Ku}, 1997$; Talbot and Kelts, 1990; Talbot, 1990). For example, $\delta^{18} \mathrm{O}$ and $\delta^{13} \mathrm{C}$ values are typically more strongly covariant in closed-basin lakes (unless alkalinity is exceedingly large, 
619 i.e., in the case of hyper-saline lakes) and weakly covariant in open-basin lakes. The principal

620 mechanism responsible for this response is the freshwater dilution effect on the isotopic composition of DIC and water. In closed-basin lakes, the influence of evaporation and primary

622 productivity increase the oxygen and carbon isotopic composition of the water and DIC pool

623 relative to that of inflowing water. When climate is wetter and lake volume is greater, more

624 isotopically depleted water enters from the catchment leading to a decrease in the water $\left(\delta^{18} \mathrm{O}\right.$

625 and $\delta \mathrm{D})$ and DIC $\left(\delta^{13} \mathrm{C}\right)$ isotopic values, and vice versa. In an open-basin system lake water that

626 is not substantially affected by evaporation, the isotopic composition of carbon and oxygen is

627 consistent with that of inflowing meteoric water, such that changes in lake productivity and the

628 effect of temperature on the calcite-water equilibrium isotopic separation are the principal

629 controls on the isotopic composition of DIC and carbonate minerals precipitating from the water 630 column, respectively.

631 The $\delta^{18} \mathrm{O}$ and $\delta^{13} \mathrm{C}$ values of authigenic $\mathrm{CaCO}_{3}$ at Cleland Lake are strongly covariant $(\mathrm{r}=$

6320.74 ) (Fig. 5), signifying that closed-basin conditions prevailed for the majority of the Holocene

633 and that lake hydrologic and isotopic balance were strongly influenced by changes in

634 precipitation-evaporation balance. At Paradise Lake, the $\delta^{18} \mathrm{O}$ and $\delta^{13} \mathrm{C}$ values of $\mathrm{CaCO}_{3}$ are

635 weakly covariant overall $(\mathrm{r}=0.23)$, suggesting greater hydrologic through-flow and more open-

636 basin conditions relative to Cleland. There are pronounced periods of both strong and weak 637 covariance in the Paradise Lake record during the late Holocene, with the most positive values 638 centered around $\sim 2,250 \mathrm{yr} \mathrm{BP}$ and $\sim 1,100 \mathrm{yr} \mathrm{BP}$, and negative values centered at 1,450 yr BP.

639 Oxygen and carbon isotope values in sediment from Lime Lake are negatively correlated $(\mathrm{r}=-$ 640 0.36), characteristic of a hydrologically open-basin system. The strong positive correlation 641 centered at $\sim 4,200 \mathrm{yr}$ BP corresponds with the most depleted $\delta^{18} \mathrm{O}$ and $\delta^{13} \mathrm{C}$ values of the 642 Holocene and may be the result of reduced temperature seasonality, weakened lake stratification 643 and cycling of organic matter from the lake sediment back into the DIC pool. Similar, positive $644 \delta^{18} \mathrm{O}-\delta^{13} \mathrm{C}$ relationships have been observed in open-basin lakes located in central North America 645 (Drummond et al., 1995).

646 The average $\delta^{18} \mathrm{O}$ value of Cleland Lake sediment from 7,600-2,600 yr BP is $-6.5 \%$, 647 substantially lower than the mean value of $-5.4 \%$ from 2,200 yr BP to present, indicating a 648 wetter mid-Holocene and drier conditions during the late Holocene (Fig. 6). Oxygen isotope 649 values are markedly lower from $\sim 2,600-2,200 \mathrm{yr} \mathrm{BP}$, with a mean value of $-8.8 \%$, signifying 
anomalously wet conditions during a multiple century interval spanning the middle to late Holocene transition. Paradise Lake $\delta^{18} \mathrm{O}$ values vary between -15.4 and $-18.8 \%$ with the lowest values occurring in sediment from the mid-Holocene and the highest values in the late Holocene, a trend that is generally consistent with the Cleland Lake data. There are notable differences between the records, however, including the incoherence at $\sim 2,400 \mathrm{yr}$ BP and after $\sim 1,500 \mathrm{yr} \mathrm{BP}$, at which point the Paradise Lake $\delta^{18} \mathrm{O}$ values begin to increase substantially while the Cleland Lake values vary around a roughly constant mean value. These disparities are likely the result of spatial heterogeneity in climate of the Pacific Northwest as well as differences in lake responses to climate forcing. Lime Lake $\delta^{18} \mathrm{O}$ values exhibit substantially less variability than those of Cleland and Paradise and generally follow a slightly increasing trend from a mean of $-15.1 \%$ from 7,600-4500 yr BP to a mean of $-14.7 \%$ after 4,500 yr BP. This positive trend in Lime Lake isotope values can be explained by colder winter temperatures (which enhance upstream rainout and produce more depleted atmospheric water vapor) (Rozanski et al., 1992), greater winter precipitation, or disparate water vapor sources during the mid-Holocene relative to present.

Changes in the isotopic composition of precipitation cannot explain the late Holocene shift to more positive values in the Cleland and Paradise sediment oxygen isotope data. The Lime Lake record indicates that isotope values in precipitation increased slightly throughout the Holocene but not to an extent that explains the substantial enrichments in both the Cleland and Paradise records. Additional support for this inference is provided by the Oregon Caves National Monument speleothem (Ersek et al., 2012) and Jellybean Lake sediment (Anderson et al., 2005), which indicate a late Holocene shift in precipitation $\delta^{18} \mathrm{O}$ values of $<0.4 \%$, substantially smaller than the $>1.0 \%$ change in the Cleland and Paradise records (Fig. 7). Mid-Holocene simulations conducted using an isotope enabled global atmospheric model further support the paleo-proxy results, suggesting that oxygen isotope values in precipitation were depleted by $\sim 0.5 \%$ during the mid-Holocene in the Pacific Northwest (Liu et al., 2014).

\subsection{Paleoclimate data from the Pacific Northwest}

In the following paleoclimate data synthesis, we focus on the mid-Holocene, which we define here as 7,500-2,500 yr BP. We concentrate on the 6,000 yr BP time period, which is of 
particular interest because, relative to the early Holocene, Northern Hemisphere summer insolation levels were still high, winter insolation levels were low, and continental ice sheets were not present (other than those of Antarctica and Greenland). The 6,000 yr BP time period therefore provides insight into climate responses to insolation forcing in the absence of ice sheets from the last glacial maximum and their potential influence on synoptic atmospheric patterns (and with minimal influence by differences in greenhouse gases and volcanic forcing relative to present). Notably, in most studies published before AD 1990, chronologies are discussed in uncalibrated radiocarbon years before present. In many cases these records were dated using bulk sediment rather than macrofossils and therefore were more likely affected by radiocarbon reservoir effects that often lead to ages that are older than the true age of deposition. These limitations make it difficult to discern the timing of events in comparative syntheses that involve older datasets. Hence, our objective is not to characterize the exact timing of transitions from the middle to late Holocene, but rather to discuss the general pattern of Holocene climate change.

The Cleland and Paradise Lake $\delta^{18} \mathrm{O}$ records are generally consistent with a visible derivative spectroscopy (VDS) analysis of sediment (different cores and age models than are discussed here) from Cleland Lake (Mihindukulasooriya et al., 2015) and with some proximal paleoclimate records from the region. Analyses of sediment from Felker Lake (diatom assemblage and pollen speciation) (Galloway et al., 2011) and Dog Lake (based on chara accumulation rates) (Hallett and Hills, 2006) suggest higher lake levels resulting from a wetter climate during the mid-Holocene followed by lower lake levels and drier conditions during the late Holocene (Fig. 7; Table 1). A multi-proxy paleolimnological record (pollen, algal pigment, and diatom assemblage analysis) from Big Lake, southern British Columbia, indicates drier conditions from 7,500-6,600 yr BP, and a wet interval from 6,600-3,600 yr BP followed by moderately dry conditions in the late Holocene from 3,600 yr BP to present (Bennett et al., 2001). Lithological analysis of sediment from Mahoney Lake, south-central British Columbia indicates a period of sustained high lake levels from 4,900-2,700 yr BP and lower lake levels from 2,700-1,600 yr BP (Lowe et al., 1997). Less proximal records that are generally consistent with this pattern include the Oregon Caves National Monument (OCNM) speleothem $\delta^{13} \mathrm{C}$ data, which indicate less precipitation during the late Holocene (Ersek et al., 2012), and the Crevice Lake $\delta^{18} \mathrm{O}$ record which suggests that winter precipitation amounts declined from the middle to late Holocene (Whitlock et al., 2012). The $\delta^{18} \mathrm{O}$ record from Castor Lake, north-central 
712 Washington, also provides support for this pattern, demonstrating a subtle, gradual transition 713 toward decreased winter precipitation in the late Holocene (Nelson et al., 2011). Located inland 714 from the Gulf of Alaska, the Marcella Lake $\delta^{18} \mathrm{O}$ record indicates that climate was less humid 715 and generally drier in the mid-Holocene relative to present (Anderson et al., 2007). Several 716 pollen records from British Columbia also support this pattern of a relatively wetter mid717 Holocene (Hebda, 1995). The differences between the middle and late Holocene average lake 718 proxy record values (depicted in Figure 7) are statistically significant at the $>90 \%$ confidence 719 level, with the differences in the lake sediment $\delta^{18} \mathrm{O}$ average values significant at the $>99 \%$ level. 720 Collectively, these datasets suggest that in the Pacific Northwest, particularly central/southern 721 British Columbia, the mid-Holocene was wetter relative to present day. The preponderance of regional evidence, however, indicates the opposite pattern; namely, that in the greater Pacific Northwest region, the mid-Holocene was drier than the late Holocene.

724 Support for this inference is provided by pollen records from a wide range of locations 725 throughout the Pacific Northwest (Hebda, 1995; Ritchie and Harrison, 1993; Whitlock and Brunelle, 2006; Whitlock, 1992) including eastern/central Oregon (Sea and Whitlock, 1995;

727 Wigand, 1987), British Columbia (Heinrichs et al., 2002, 2001; Mathewes and King, 1989; 728 Mathewes, 1985; Pellatt et al., 2000, 1998; Reasoner and Hickman, 1989), Idaho (Beiswenger, 1991; Brunelle and Whitlock, 2003; Doerner and Carrara, 2001; Mack et al., 1978a; Pierce et al., 2004; Whitlock et al., 2011), eastern Washington (Mack et al., 1979, 1978b, 1978c; Whitlock, 1992), western Montana (Mack et al., 1983; Mehringer Jr. et al., 1977; Power et al., 2006), and northwestern Wyoming (Baker, 1976; Huerta et al., 2009; Millspaugh et al., 2004, 2000; Whitlock and Bartlein, 1993; Whitlock, 1993), the vast majority of which indicate higher 734 summer temperatures and/or lesser precipitation amounts during the mid-Holocene. Diatom and chironomid assemblage data from southern British Columbia (Chase et al., 2008; Heinrichs et al., 1999; Palmer et al., 2002; Pellatt et al., 2000; Reasoner and Hickman, 1989; Rosenberg et al., 737 2004), and northwestern Montana (Stone and Fritz, 2006) provide additional evidence in support 738 of this pattern. The Crevice Lake multi-proxy record from southwestern Montana (northern Yellowstone National Park) is particularly insightful in that it provides information on climate in various seasons (Whitlock et al., 2012). Pollen from Crevice Lake sediment cores supports the idea of a drier mid-Holocene and a wetter late Holocene; whereas the Crevice Lake $\delta^{18} \mathrm{O}$ record indicates that winters were wetter in this region during the mid-Holocene. Analyses of lake-level 
changes in western Montana and northwestern Wyoming (Shuman et al., 2010, 2009) from sedimentology (grain size) and seismic surveys further support the notion of a dry mid-Holocene. These datasets are generally consistent with numerous other palynological studies from British Columbia that suggest a warmer and likely drier climate during the mid-Holocene from $\sim 7,800$ 5,100 yr BP (Hebda, 1995).

In order to reconcile the markedly contrasting perspective on mid-Holocene climate provided by these two groups of proxy records, we assert that mid-Holocene climate in the Pacific Northwest was characterized by enhanced seasonality of both temperature and precipitation, such that conditions were wetter in the cold season due principally to greater precipitation amounts, and drier in the warm season due to lesser precipitation amounts and higher temperatures, relative to present. This scenario produced drier overall climatic conditions (due to a substantially reduced summer precipitation-evaporation balance) that were recorded by some lake sediment (and other paleo-archive) proxies. The disparity between these datasets and the lake sediment oxygen and carbon isotope records can be explained by the inherent cold season sensitivity of closed-basin lake hydrology and isotope dynamics (as evinced by the lake model climate sensitivity simulations). The low $\delta^{18} \mathrm{O}$ values in closed-basin lake sediment from this time therefore resulted from greater precipitation amounts and cooler temperatures (which reduced evapotranspiration) during the cold season, and comparatively lesser sensitivity to the substantially drier conditions that occurred during the warm season.

\subsection{Holocene changes in synoptic patterns of ocean-atmosphere variability}

Differences between orbital parameters at 6,000 yr BP and present are the primary reason for the climatic disparity between the two time periods. Radiative forcing at the top of the atmosphere was greater during summer in the northern hemisphere and lesser during winter, and the lengths of the seasons were shifted such that summers were shorter (by 4-5 days) and winters were longer (Berger, 1978). This led to increased insolation in the shorter summer season. Earth's obliquity was also greater at 6,000 yr BP, resulting in increases in summer and annual mean insolation in the high latitudes of both hemispheres. These differences in orbital parameters (mainly in precession) produced changes in the length and amplitude of the seasons relative to present, which influenced the evolution of lacustrine phototrophic communities 
774 (Mihindukulasooriya et al., 2015) and directly forced climate in western North America by 775 increasing summer temperature and evapotranspiration and likely increasing the spatial extent and temporal length of winter snowpack as a result of lower winter temperatures. Furthermore, higher summer insolation amounts affected climate in the Northern Hemisphere through effects on the global ocean atmosphere system, particularly in the tropical Pacific (Bartlein et al., 1998; Braconnot et al., 2012, 2011, 2006; Diffenbaugh et al., 2006; Harrison et al., 2003; Kutzbach et al., 1998, 1993; Liu et al., 2000; Shin et al., 2006; Zheng et al., 2008).

Modeling experiments (An and Choi, 2014; Brown et al., 2008; Chiang et al., 2009; Clement et al., 2001, 2000; Donders et al., 2008; Emile-Geay et al., 2007; Liu et al., 2000; Zheng et al., 2008) and analyses of paleo-proxy data (Barron and Anderson, 2011; Conroy et al., 2008; Donders et al., 2005; Jones et al., 2015; Koutavas and Joanides, 2012; Koutavas et al., 2006; Marchant et al., 1999; Marchitto et al., 2010; Moy et al., 2002; Rein et al., 2005; Riedinger et al., 2002; Rodbell et al., 1999; Stott et al., 2007, 2004) have shown that changes in ENSO throughout the Holocene were likely driven by ocean-atmosphere feedbacks in the Pacific and Atlantic ocean basins combined with the influence of direct insolation forcing (Fig. 8; Table 1). The majority of this work suggests that the tropical Pacific was characterized by an attenuation of ENSO variance (Conroy et al., 2008; Koutavas and Joanides, 2012; Koutavas et al., 2006; Moy et al., 2002; Rein et al., 2005; Riedinger et al., 2002; Rodbell et al., 1999), a more La Niñalike mean state (Marchitto et al., 2010; Stott et al., 2007, 2004), and a more northerly position of the ITCZ (Haug et al., 2001), which affected climate teleconnections on a global scale. Several notable studies, however, do not support these conclusions, indicating that we do not fully understand the state of the tropical Pacific Ocean during the mid-Holocene. Cobb et al., (2013), for example, present coral $\delta^{18} \mathrm{O}$ records from the Palmyra islands that (intermittently) span the past 7,000 years and indicate that mid-Holocene ENSO activity was not substantially attenuated; they further claim that forced changes in ENSO may be difficult to detect against a background of large internal variability. Sea surface temperature (SST) records derived from measurements of $\mathrm{Mg} / \mathrm{Ca}$ ratios and $\delta^{18} \mathrm{O}$ values of foraminifera in ocean sediments from the eastern Pacific cold tongue and west pacific warm pool indicate a cooler eastern tropical Pacific (Marchitto et al., 2010), a warmer western tropical Pacific, and a reduction in ENSO variance (Koutavas and Joanides, 2012; Koutavas et al., 2006; McGregor and Gagan, 2004) during the mid-Holocene. The La Niña-like sea surface temperature pattern likely enhanced the equatorial trade winds (An, 
2011) and upwelling along the Peru margin prior to 4,000 yr BP, as suggested by mollusk midden assemblages (Sandweiss et al., 2001, 1996). However, this inference is in disagreement with foraminifera assemblage and $\delta^{18} \mathrm{O}$ records from the central Chilean coast, which indicate less intensive upwelling during the mid-Holocene (Marchant et al., 1999; Mohtadi et al., 2004). Disparity between these records implies that the exact location and timing of ocean circulation changes for the tropical South American coast is not entirely understood. Lake sediments from Ecuador (Moy et al., 2002; Rodbell et al., 1999) and the Galapagos Islands (Conroy et al., 2008; Riedinger et al., 2002), geo-archeological evidence from coastal Peru (Sandweiss et al., 1996), and corals from Papua New Guinea (Tudhope et al., 2001) indicate either a more La Niña-like mean state or an attenuation of ENSO variance during the mid-Holocene, and that after $\sim 3,500 \mathrm{yr}$ BP ENSO gradually strengthened in transition to the modern configuration.

Several studies from northerly Pacific locations suggest that during the mid-Holocene the Pacific and Atlantic ocean-atmosphere systems were in substantially different configurations relative to present day. Oxygen isotope records from the northeastern Pacific basin (Anderson et al., 2005; Fisher et al., 2008) provide insight into Gulf of Alaska atmospheric circulation during the Holocene that appear to show generally weak Pacific Ocean forcing with attenuated ENSO/PDO-like variability during the mid-Holocene, an assertion supported by records of biologic productivity from the Gulf of Alaska (Addison et al., 2012; Barron and Anderson, 2011; Barron et al., 2009). An ice rafted debris (IRD) record from the Kara Sea provides insight on atmospheric pressure patterns and winds associated with the NAM (Darby et al., 2012) (Fig. 8). Low IRD fluxes from 7,500-3,000 yr BP indicate more negative NAM/AO conditions (consistent with (Sachs, 2007)); however, sea surface temperature reconstructions from the Red Sea, Atlantic and Mediterranean Oceans contradict these results, indicating a more positive AO/NAO during the mid-Holocene (Kim et al., 2004; Rimbu, 2003; Rimbu et al., 2004). These apparent contradictions in paleo-records from the Atlantic and Pacific Ocean basins make it difficult to interpret paleoclimate proxy records from the mid-Holocene in the context of changes in the NAM.

Climate model analyses of ENSO responses to mid-Holocene insolation forcing provide insight into the specific physical mechanisms responsible for the different climatic configuration at this time. For example, early work using an intermediate complexity ocean-atmosphere model (Zebiak and Cane, 1987) forced by orbital precession (Clement et al., 2001, 2000; Emile-Geay et 
al., 2007), as well as some fully coupled models from the PMIP2 (Braconnot et al., 2007; Zheng et al., 2008) and PMIP3 projects (An and Choi, 2014; Braconnot et al., 2012) (in which boundary conditions were fixed) indicate reduced ENSO variability at 6,000 yr BP relative to that of the recent, preindustrial time period (i.e. AD 1850). In the intermediate complexity model simulations, the mid-Holocene attenuation of ENSO results from the following mechanism: an insolation driven surface heating occurs during boreal summer that produces an easterly wind anomaly in the Central Pacific that, through ocean-atmosphere interactions associated with the Bjerknes Feedback, cool the eastern tropical Pacific and thereby suppress the development of El Niño events in the fall season when, in the present day configuration, ENSO events develop rapidly. These modeling studies complement ongoing paleoclimate-based studies of past changes in tropical Pacific responses to external forcing.

The lower $\delta^{18} \mathrm{O}$ values at Cleland Lake and Paradise Lake during the mid-Holocene imply that climate was wetter during this time likely as a result of La Niña-like mean state conditions in the tropical Pacific Basin (Fig. 8) that enhanced precipitation and snowpack during the cold season. Although the modern association between La Niña events and cold season hydroclimate responses in the Pacific Northwest (Fig. 1) is an unsuitable analogue for similar relationships during the mid-Holocene (due to climatic non-stationarity resulting from changes in orbital parameters), the strong correlation between the Cleland and Paradise lake records (and several other proximal records) indicates that gradual changes in the ENSO mean state throughout the Holocene influenced hydroclimatic conditions in the Pacific Northwest in a manner at least somewhat consistent with modern ENSO climatology.

\subsection{Mid-Holocene Paleoclimate modeling}

To test the $\delta^{18} \mathrm{O}$-derived hypothesis that summer climate was drier and winter climate was wetter (relative to preindustrial conditions, i.e., AD 1850) in the Pacific Northwest during the mid-Holocene, we analyzed output from climate model experiments conducted using MPIESM-P and MRI-CGCM3 (described in Materials and Methods, above) as part of PMIP3/CMIP5. Comparison of the 6,000 yr BP and preindustrial control simulations provides insight on how mid-Holocene boundary conditions (primarily insolation) could have produced climate conditions consistent with proxy records from the Pacific Northwest, and in particular 
867 the $\delta^{18} \mathrm{O}$ data from Cleland, Paradise, and Lime lakes. Results from these simulations are largely 868 similar to those of other models (Bartlein et al., 2014, 1998; Diffenbaugh and Sloan, 2004;

869 Diffenbaugh et al., 2006; Harrison et al., 2003; Kutzbach et al., 1993; Qin et al., 1998; Shin et 870 al., 2006), indicating generally drier annual conditions in much of the North America west, 871 particularly in the summer months when insolation and temperature were higher (Fig. 9).

872 Analysis of the seasonal trends in the model data reveal a dry warm season throughout much of 873 western North America, with the exception of the southwest, where precipitation amounts were 874 greater in some areas due to an enhanced North American Monsoon (Metcalfe et al., 2015). 875 Consistent with our interpretation of the $\delta^{18} \mathrm{O}$ data, the cold season was relatively wetter in much 876 of western North America in the model simulations, particularly along the western coast and in 877 the Pacific Northwest, but was drier in the central and southern Rocky Mountains. Both models 878 indicate a strengthening of westerly wind flow in the Pacific Northwest (Supplemental 879 Information; Figs. S8,S9) and a consequent increase in precipitation in much of coastal western 880 North America during the cold season, particularly in California, Washington, and 881 central/southern British Columbia. In general, results from these climate model analyses provide 882 support for the physical plausibility of our hypothesis that wetter conditions occurred in the 883 PNW in winter, with drier conditions in summer, leading to an overall drier climate but with 884 885 886 887 888 enhanced seasonality during the mid-Holocene.

The models are generally consistent in simulating a slight increase in winter precipitation-evaporation balance in the northern Rockies (the proxy evidence for which is discussed above), a reduction of winter precipitation in the central and southern Rockies, and marginally wetter conditions in the southwest resulting from greater summer precipitation. Oxygen isotope records of precipitation-evaporation balance changes in northwestern Colorado, which lies close to the axis region of the ENSO / NAM climatology pattern (Fig. 1), indicate that 892 proxy data from lake sediment lithology/geochemistry (southern California) (Li et al., 2008), 893 pollen (Arizona) (Mehringer et al., 1967), and midden (Arizona, southern California) (Holmgren 894 et al., 2010, 2006; McAuliffe and Van Devender, 1998) studies suggest that mid-Holocene 895 climate at 6,000 yr BP was wetter than present in some areas of the southwest, perhaps in 896 response to the strengthened North American monsoon (Metcalfe et al., 2015). Other studies of 897 lake sediment lithology/geochemistry (southern California, New Mexico, Arizona) (Bird and 
Kirby, 2006; Bird et al., 2010; Kirby et al., 2015, 2013, 2012, 2010; Krider, 1998; Menking and Anderson, 2003; Waters, 1989), pollen (New Mexico, Arizona) (Jiménez-Moreno et al., 2008; Markgraf et al., 1984; Weng and Jackson, 1999), and speleothems (Asmerom et al., 2007; Lachniet et al., 2014; Steponaitis et al., 2015), however, are at least somewhat inconsistent with this pattern and instead suggest that drier conditions prevailed at this time. Notably, of the records that indicate dryness at 6,000 yr BP, several (Bird and Kirby, 2006; Bird et al., 2010; Krider, 1998; Waters, 1989; Weng and Jackson, 1999) impart that by 4,000 yr BP climate may have become wetter. Collectively, these data provide support for the model simulations of midHolocene climate presented here, although in some regions (e.g. southern California) substantial disparity exists between the model results and proxy data. A complete assessment of paleoclimate information from the southwest in the context of climate model simulations (Harrison et al., 2003, 2015, 2014; Metcalfe et al., 2015) is beyond the scope of this study but would help to reconcile proxy-model inconsistencies and provide further insight into the evolution of the North American monsoon during the Holocene and, in particular, its impact on seasonality of precipitation in the southwest.

\subsection{The 2,400 yr BP Cleland Lake isotope anomaly}

The Cleland $\delta^{18} \mathrm{O}$ record exhibits several non-stationary negative isotopic shifts from 7,000-6,500 yr BP, 2,600-2,200 yr BP, and 1,100-500 yr BP, with the longest centered around 2,400 yr BP (Fig. 6). During this period $\delta^{18} \mathrm{O}$ values decreased by about $6 \%$ over a relatively short time. Lake model results indicate that an exceptionally (perhaps unrealistically) large, increase in precipitation-evaporation balance is required to force an isotopic change of this magnitude, and point toward other sources of $\delta^{18} \mathrm{O}$ variability, possibly resulting from non-linear lake catchment responses to climate change related to hypsography and/or lake outflow characteristics unaccounted for by the model (Steinman and Abbott, 2013; Steinman et al., 2010b). For example, large isotopic depletions could be caused by surficial overflow (in July 2012 Cleland Lake water levels were $\sim 2 \mathrm{~m}$ below the overflow level) due to wetter conditions, which would have reduced the proportion of water lost via evaporation. However, there is no geomorphic evidence of the Cleland Lake outlet having been at a substantially higher elevation in the past. This implies that the anomalous 2,600 yr BP excursion was not associated with a 
rapid down-cutting event and a subsequent change in the lake outflow regime, which could erroneously be invoked to explain the mean state isotopic shift to more positive values after 2,400 yr BP. The most likely cause of the excursion is therefore a substantial change in hydroclimatic conditions in at least the immediate vicinity of Cleland Lake. The Felker Lake salinity and lake-level records provide some support for a large, positive shift in precipitationevaporation balance during this time in Southern British Columbia, but no other records, including that of Dog Lake, which is $33 \mathrm{~km}$ from Cleland Lake, support this idea (Fig. 7). Interestingly, a multi-proxy assessment of sediment from Stonehouse Meadow, Nevada, indicates that widespread drought occurred from $\sim 2,800-1,850 \mathrm{yr}$ BP and that the transition to drier conditions occurred rapidly over several hundred years (see Mensing et al., 2013 and references therein). The timing of this large magnitude event is somewhat consistent with the 2,600 yr BP excursion in the Cleland Lake data, although the Stonehouse Meadow event persists for slightly longer, suggesting that opposite hydroclimate responses in the northern and southern regions of western North America may have occurred on centennial timescales at this time in response to Pacific ocean-atmosphere variability (i.e. similar to the modern dipole relationship between precipitation and ENSO (Wise, 2010)). These results underscore the need to consider non-linearity in paleoclimate proxy responses to climate change, as well as the substantial influence of complex topography and orographic effects on regional climate change.

\section{Conclusions}

Lake modeling analyses combined with historical climate data comparisons indicate that the oxygen isotopic composition of Cleland and Paradise lake sediment is strongly influenced by precipitation-evaporation balance, particularly in the cold season. Isotopic measurements indicate that Lime Lake has a high rate of through-flow, a low proportion of water loss via evaporation, and consequently, water and sediment isotope values that reflect the isotopic composition of meteoric water. Collectively, $\delta^{18} \mathrm{O}$ records from these lakes provide insight into Holocene hydroclimate changes in the Pacific Northwest.

Low $\delta^{18} \mathrm{O}$ values in Cleland Lake sediment from 7,600-2,200 yr BP, (and particularly from 2,600-2,200 yr BP) indicate that cold season climatic conditions in southern British Columbia were wetter at this time, and that after 2,200 yr BP drier conditions prevailed (Fig. 6). 
960 Paradise Lake sediment $\delta^{18} \mathrm{O}$ values support the idea of a transition from wetter to drier 961 conditions from the middle to late-Holocene, although the Paradise Lake record indicates a more 962 gradual transition than does the Cleland Lake record and an earlier onset of the drying trend.

963 Isotope data from Lime Lake provide a complimentary perspective, demonstrating that 964 precipitation isotope values generally increased during the Holocene, but to far less of an extent required to explain the large magnitude isotopic shifts in the closed-basin records. These datasets combined with the lake modeling results suggest that mid-Holocene climate in the Pacific Northwest was characterized by lower cold season temperatures and greater cold season precipitation amounts.

Analysis of several PMIP3 simulations of mid-Holocene climate support the pattern evinced by the lake sediment data. The model experiments indicate that western North America was drier than present at 6,000 yr BP due to large warm season precipitation-evaporation balance anomalies, but that cold season climatic conditions were relatively wetter (Fig. 9). This enhancement of hydroclimate seasonality, as well as the substantial spatial heterogeneity in model simulations, helps to explain the disparity between some proxy records from central/southern British Columbia that indicate wetter conditions during the mid-Holocene, and the majority proxy data from the greater Pacific Northwest region, which indicate a drier overall climate. The lake and climate model experiments further suggest that inconsistency between proxies could be the result of seasonal sensitivity, in that lake sediment $\delta^{18} \mathrm{O}$ records represent cold season hydroclimatic conditions.

Ocean-atmosphere proxy records and climate model simulations suggest that the tropical

982 variability during the mid-Holocene to a more El Niño-like mean state with enhanced ENSO

983 variability in the late Holocene (Fig. 8). This change in the ocean-atmosphere system is reflected

984 by the lake sediment isotope data, which reveal a pattern of climate change that is at least

985 somewhat consistent with the current relationship between ENSO/NAM and precipitation in 986 western North America (i.e., a positive ENSO phase leads to a drier cold season, and vice versa) 987 (Fig.1). This apparent coherence between observed and inferred Holocene relationships between 988 ENSO and hydroclimate in the west should be viewed cautiously, however, as gradual changes 989 in external forcing likely produced non-stationarity in the climate system that cannot be 990 accounted with the modern analogue. A pronounced negative $\delta^{18} \mathrm{O}$ excursion in the Cleland Lake 
$991 \delta^{18} \mathrm{O}$ record centered on $\sim 2,400 \mathrm{yr}$ BP indicates an exceptionally wet period that may have been 992 isolated to the immediate vicinity of Cleland Lake, highlighting the potential for abrupt

993 hydroclimatic change as well as substantial intra-regional heterogeneity in response to gradual 994 external forcing.

995 The Cleland, Paradise, and Lime lake $\delta^{18} \mathrm{O}$ records demonstrate that past mean-state 996 shifts in the ocean-atmosphere system in response to orbital forcing produced considerable 997 changes in the climate of the Pacific Northwest. Moreover, these records imply that future, 998 externally forced changes in the mean-state of ENSO and other internal climate modes may have 999 substantial effects on hydroclimate variability in the Pacific Northwest and across western North 1000 America. The degree to which the various external forcing factors, namely, changes in the 1001 orbital configuration, anthropogenic greenhouse gas emissions, as well as climate system 1002 feedbacks involving the ocean, atmosphere, and land (i.e., vegetation and orographic controls), 1003 influence climate change in western North America requires further investigation. To this end, 1004 additional high resolution paleoclimate records should be developed and analyzed in the context 1005 of temporally continuous Holocene length simulations conducted using Earth System models 1006 capable of resolving localized climate system responses to larger, synoptic scale climate 1007 variability.

\section{Acknowledgements}

1011 This research was supported by funding from National Science Foundation to the University of 1012 Pittsburgh (EAR-0902200) and Kent State University (EAR-0902753). B.A.S acknowledges 1013 support from the U.S. National Science Foundation: (AGS-1137750, EAR-1502740). D.P.P. 1014 recognizes support from the Mellon Predoctoral Fellowship through the Andrew Mellon 1015 Foundation. University of Delaware Air Temperature and Precipitation data were provided by 1016 the NOAA/OAR/ESRL PSD, Boulder, Colorado, USA, from their web site at 1017 http://www.esrl.noaa.gov/psd/. 
1022 Table 1. T-test analysis results

\begin{tabular}{|c|c|c|c|c|c|c|c|}
\hline Lake/Site Name & Proxy & Reference & $-50-2500 \mathrm{yr} B P$ & $\begin{array}{c}\mathbf{n} \\
\text { yr BP }\end{array}$ & $2500-7500$ yr BP & $\begin{array}{c}\mathbf{n} \\
0 \mathrm{yr} B P\end{array}$ & \multirow{2}{*}{$\begin{array}{c}\text { P-value } \\
0.007\end{array}$} \\
\hline Cleland Lake, BC & Carbonate $\delta^{18} \mathrm{O}$ & this study & -5.70 & 511 & -6.62 & 1001 & \\
\hline Lime Lake, WA & Carbonate $\delta^{18} \mathrm{O}$ & this study & -14.75 & 511 & -15.00 & 1001 & 0.006 \\
\hline Paradise Lake, BC & Carbonate $\delta^{18} \mathrm{O}$ & this study & -16.87 & 511 & -17.95 & 1001 & 0.002 \\
\hline Felker Lake, BC & Diatom - lake level & Galloway et al., 2011 & 7.83 & 21 & 9.37 & 30 & 0.055 \\
\hline Felker Lake, BC & Diatom - lake salinity & Galloway et al., 2011 & 280.4 & 21 & 205.5 & 30 & 0.053 \\
\hline Dog Lake, BC & Chara accumulation & Hallett and Hills, 2006 & 0.04 & 16 & 0.26 & 118 & 0.086 \\
\hline Crevice Lake, WY & Carbonate $\delta^{18} \mathrm{O}$ & Whitlock et al., 2012 & -7.72 & 189 & -9.49 & 62 & 0.002 \\
\hline Oregon Cave, OR & Speleothem $\delta^{18} \mathrm{O}$ & Ersek et al., 2012 & -8.80 & 760 & -8.92 & 1874 & 0.004 \\
\hline Windy Lake, BC & Chirdonomid - JA temp & Chase et al., 2008 & 0.05 & 128 & 0.76 & 250 & 0.027 \\
\hline Beaufort Sea (JPC16) & Fe grain IRD - AO & Darby et al., 2012 & 5.36 & 125 & 4.02 & 251 & 0.133 \\
\hline Soledad Basin & $\mathrm{Mg} / \mathrm{Ca}$ inferred SST & Marchitto et al., 2010 & 17.12 & 14 & 16.02 & 67 & 0.124 \\
\hline Cariaco Basin & Titanium & Haug et al., 2001 & 0.19 & 431 & 0.28 & 893 & 0.028 \\
\hline El Junco, Galapogos & Sand percent & Conroy et al., 2008 & 8.11 & 174 & 2.96 & 137 & 0.013 \\
\hline Pacific Warm Pool & $\mathrm{Mg} / \mathrm{Ca}$ inferred SST & Khider et al., 2014 & 27.59 & 139 & 27.79 & 164 & 0.044 \\
\hline Pacific Warm Pool & $\mathrm{Mg} / \mathrm{Ca}$ inferred SST & Stott et al., 2004 & 28.78 & 69 & 29.10 & 92 & 0.081 \\
\hline
\end{tabular}

1023

1024

1025

1026

1027

1028

1029

1030

1031

1032

1033

1034

1035

1036

1037

1038

1039

1040 

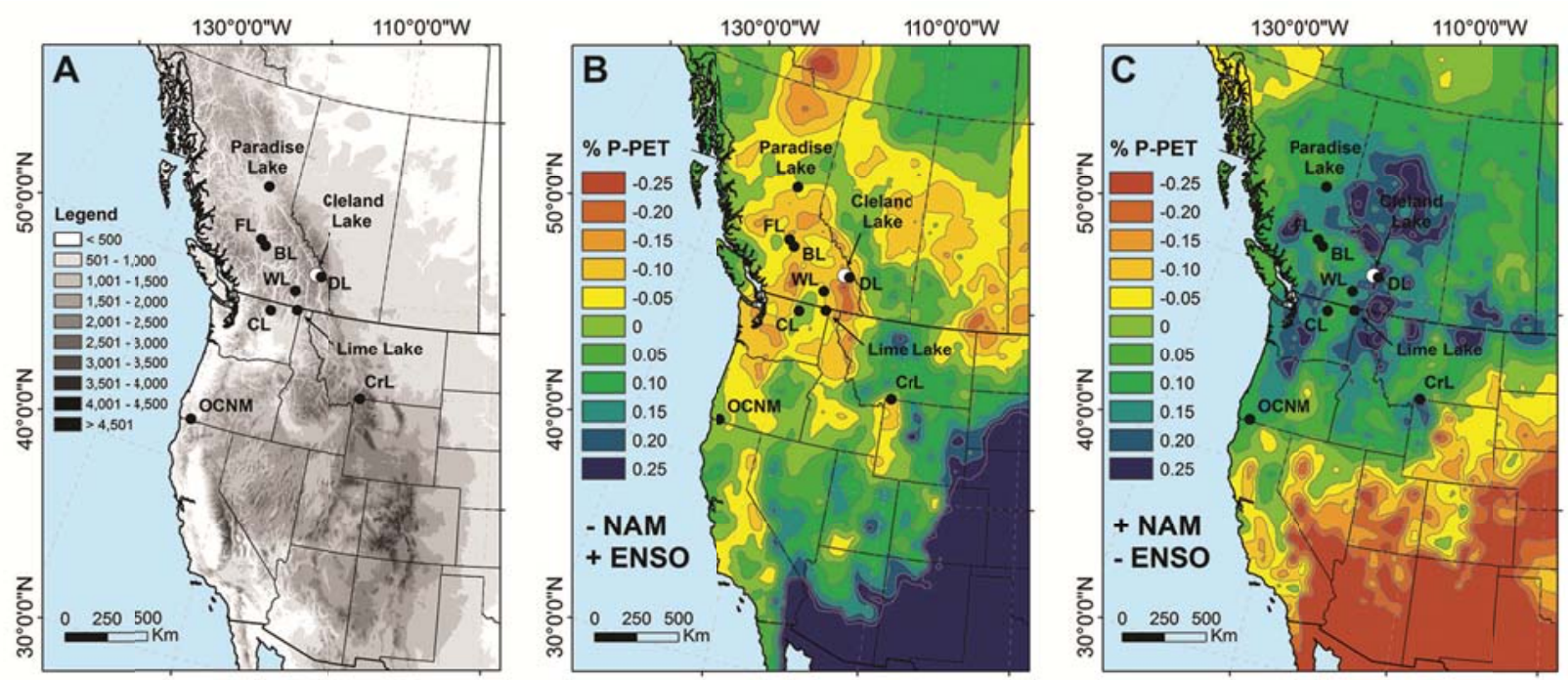

1043 Figure 1. A) Regional digital elevation map (DEM) of the Pacific Northwest and southwestern 1044 United States. The locations of Cleland Lake (white circle) and other regional lake sediment 1045 proxy records (black circles) are shown including Lime Lake, Paradise Lake, Oregon Cave 1046 National Monument (OCNM), Crevice Lake (CrL), Castor Lake (CL), Windy Lake (WL), Dog 1047 Lake (DL), Felker Lake (FL), and Big Lake (BL). B) Change in October-March precipitation 1048 minus potential evapotranspiration (PET) (relative to total October-March precipitation) during 1049 1050 years of negative ENSO and positive NAM, and C) vice versa (values are expressed as a 1051 fraction, e.g., 0.25 is the equivalent of 25\%) (Steinman et al., 2014). 


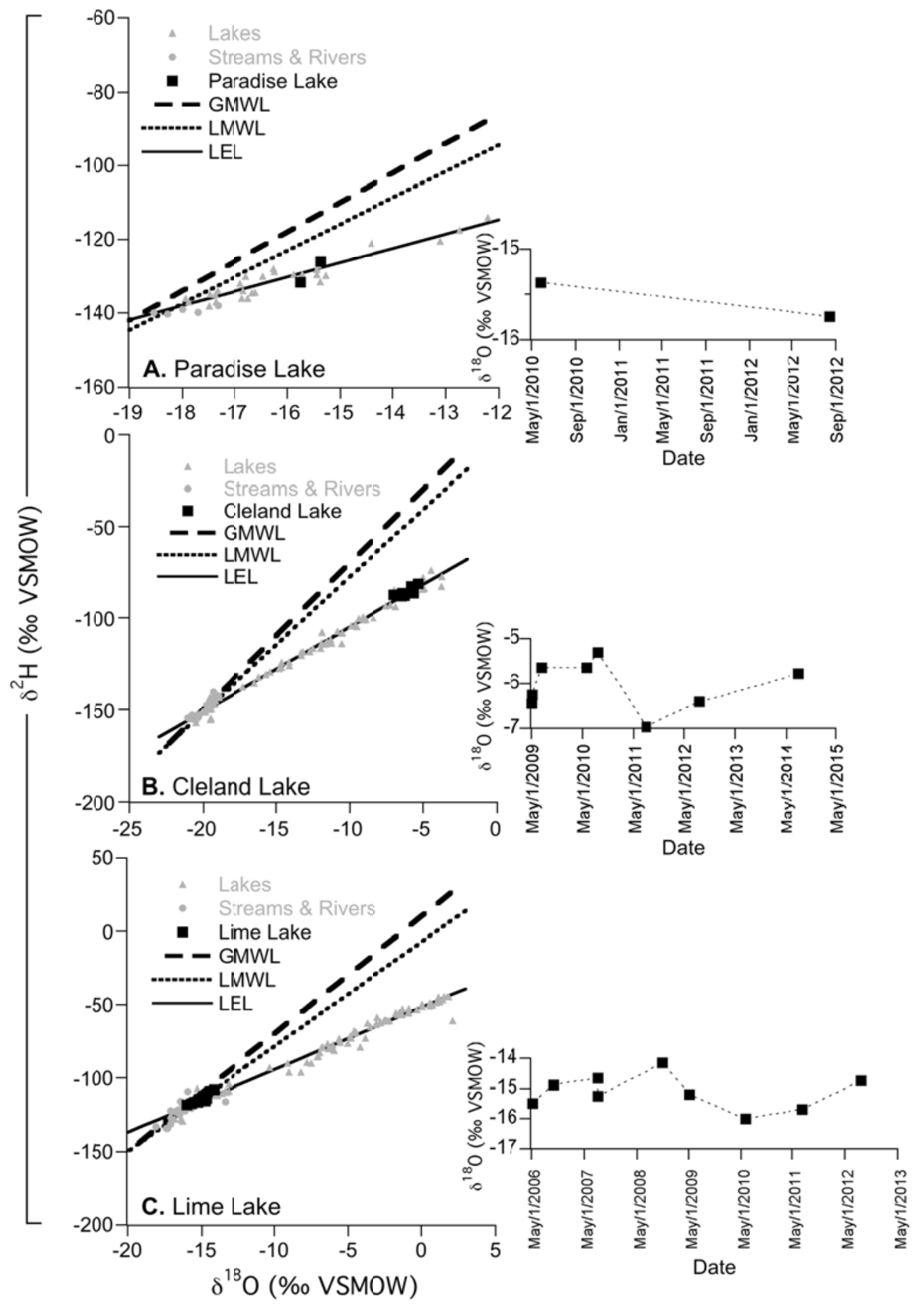

1054

1055

1056

1057

1058 1059
Figure 2. Regional surface water isotope data from AD 2009-2014 and relationship with the global meteoric water line (GMWL), local meteoric water line (LMWL) and local evaporation line (LEL) for Paradise Lake (A), Cleland Lake (B), and Lime Lake (C). Insets depict time series of oxygen isotope values of lake surface water. 


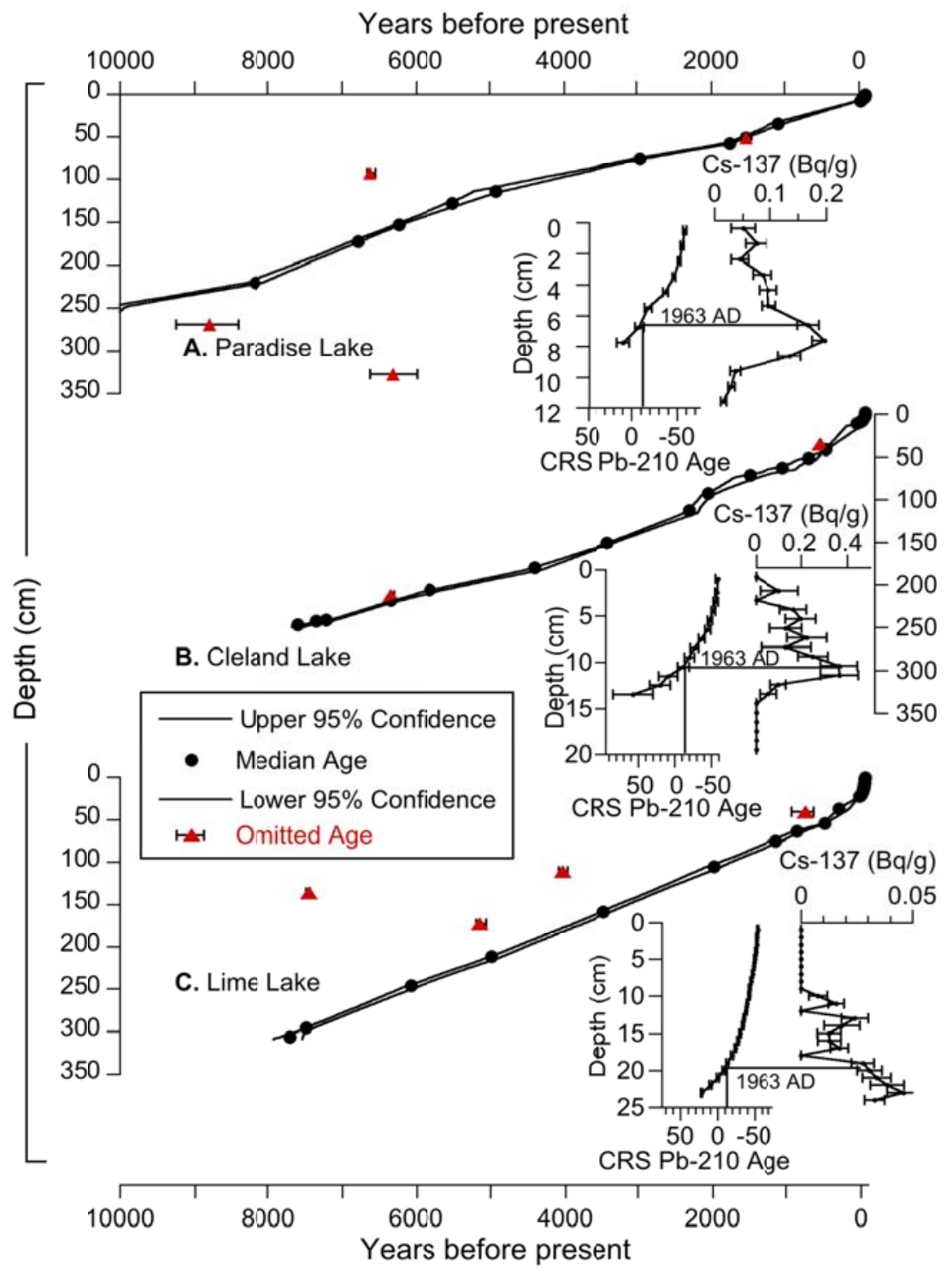

1061

1062

1063

1064

1065

1066

1067
Figure 3. Linear point-to-point age-models from CLAM 2.2 (Blaauw, 2010) produced using radiocarbon, tephra dating, $\mathrm{CRS}{ }^{210} \mathrm{~Pb}$ and ${ }^{137} \mathrm{Cs}$ measurements (inset) for Paradise Lake (A), Cleland Lake (B) and Lime Lake (C). 


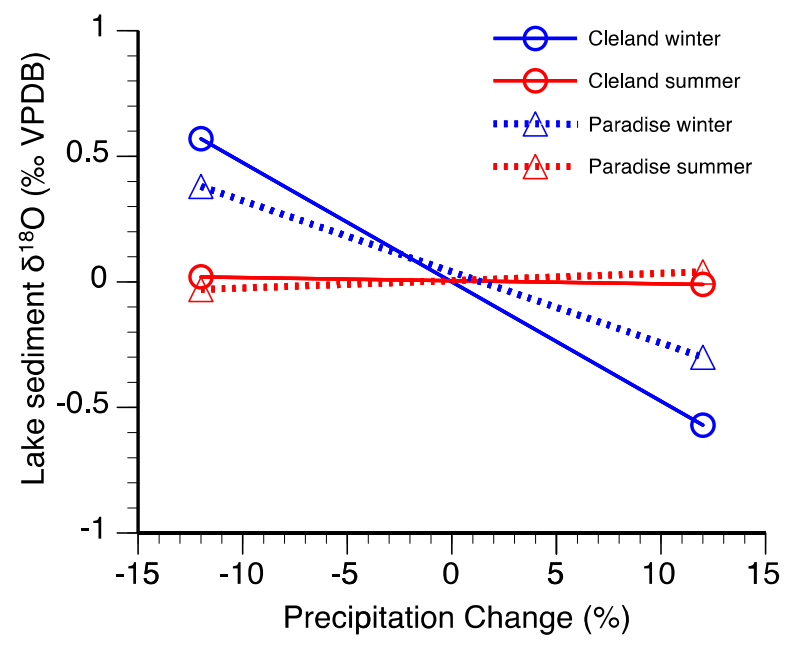

1068

1069

1070

1071

1072

1073

1074

1075

1076

1077

1078

1079

1080

1081
Figure 4. Lake model steady-state climate sensitivity simulation results. Modeled lake sediment $\delta^{18} \mathrm{O}$ responses to changes in precipitation $( \pm 12 \%)$ and temperature $(C, D)\left( \pm 0.6{ }^{\circ} \mathrm{C}\right)$ during cold season (October-March) (blue) and warm season (April-September) (red).

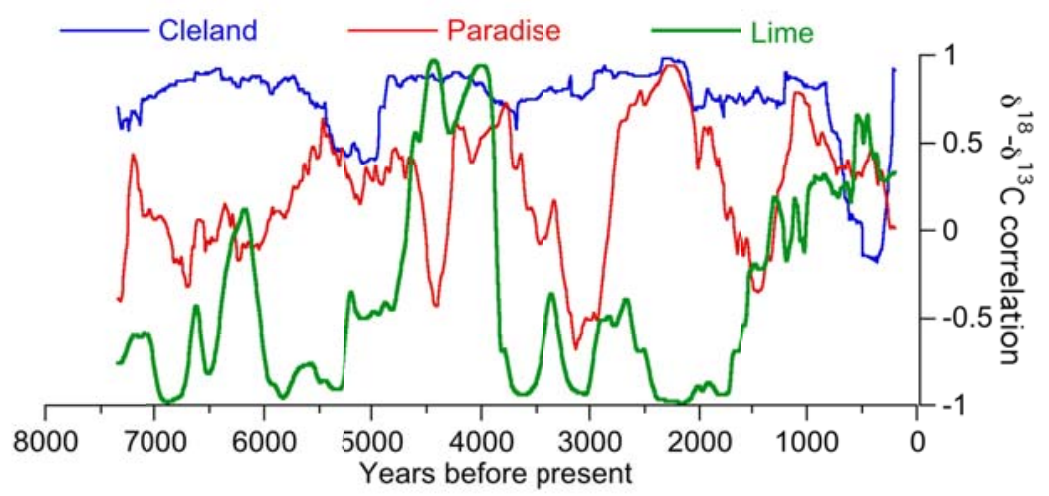

Figure 5. 500 year moving average carbonate mineral oxygen and carbon isotope correlation (r) for Paradise Lake, Cleland Lake, and Lime Lake. 


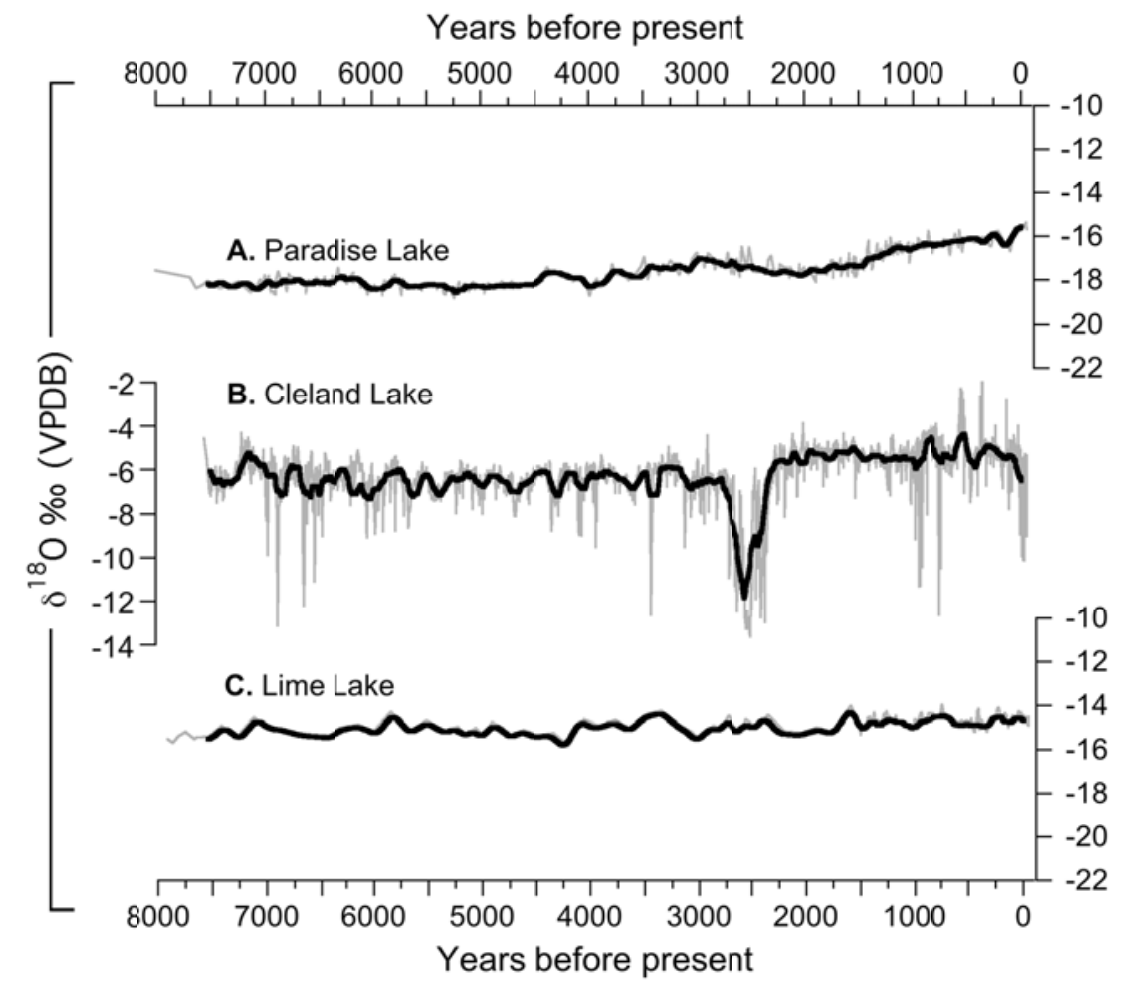

1082

1083

1084

1085

1086

1087

1088

1089

1090

1091

1092

1093

1094

1095

1096

1097

1098

1099
Figure 6. Sediment carbonate $\delta^{18} \mathrm{O}$ records (grey lines) from (A) Paradise Lake, (B) Cleland Lake and (C) Lime Lake with variable weighted smoothed lines (black lines). 


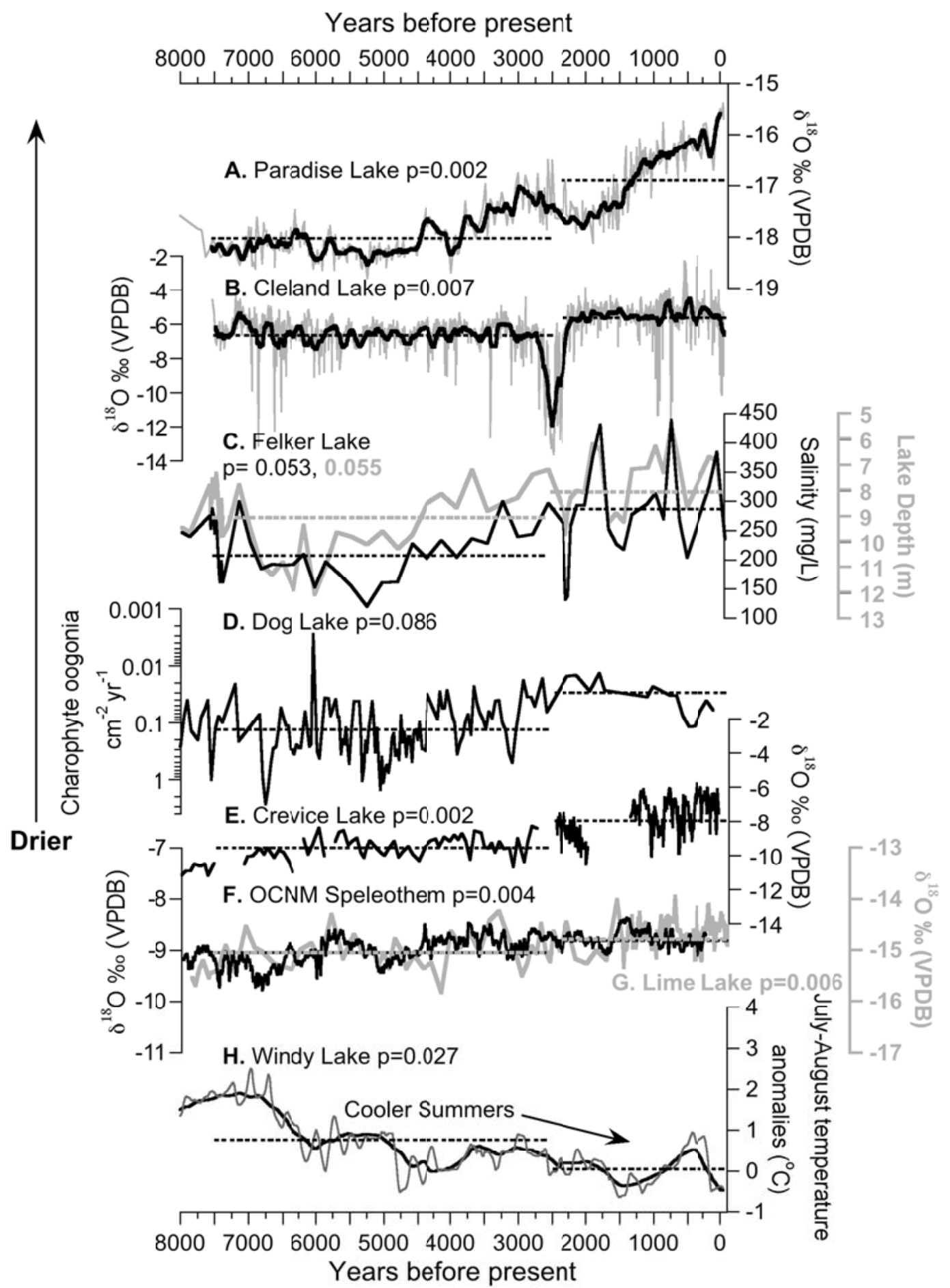

1100

1101

1102

1103

1104

1105

1106

1107
Figure 7. Regional proxy record comparison. (A) Paradise Lake and (B) Cleland Lake $\delta^{18} \mathrm{O}$ records. (C) Felker Lake diatom-based salinity and lake depth reconstruction (Galloway et al., 2011). (D) Chara accumulation rate record from Dog Lake (Hallett and Hills, 2006). (E) Crevice Lake $\delta^{18} \mathrm{O}$ record (Whitlock et al., 2012). (F) Speleothem $\delta^{18} \mathrm{O}$ record from Oregon Caves National Monument (OCNM) (Ersek et al., 2012). (G) Lime Lake $\delta^{18} \mathrm{O}$ record. (H) Chironomidbased July to August temperature reconstruction from Windy Lake (Chase et al., 2008). Dashed lines depict mean values during the middle (7,500-2,500 yr BP) and late (2,500 yr BP to present) 
1108 Holocene, with p-values indicating the statistical significance of the difference in mean values between the two time periods (see Table 1 for additional detail).
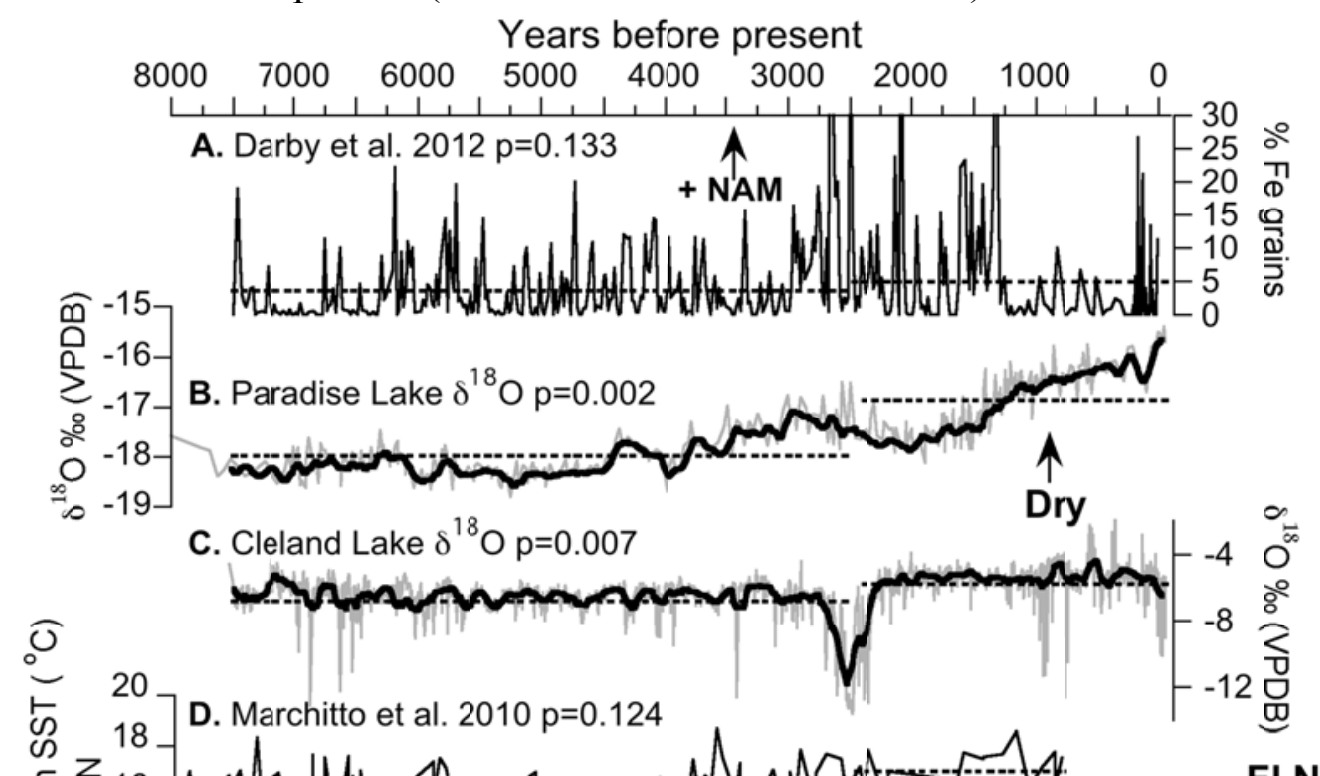

1110

1111

1112

1113

1114

1115

1116 Years before present
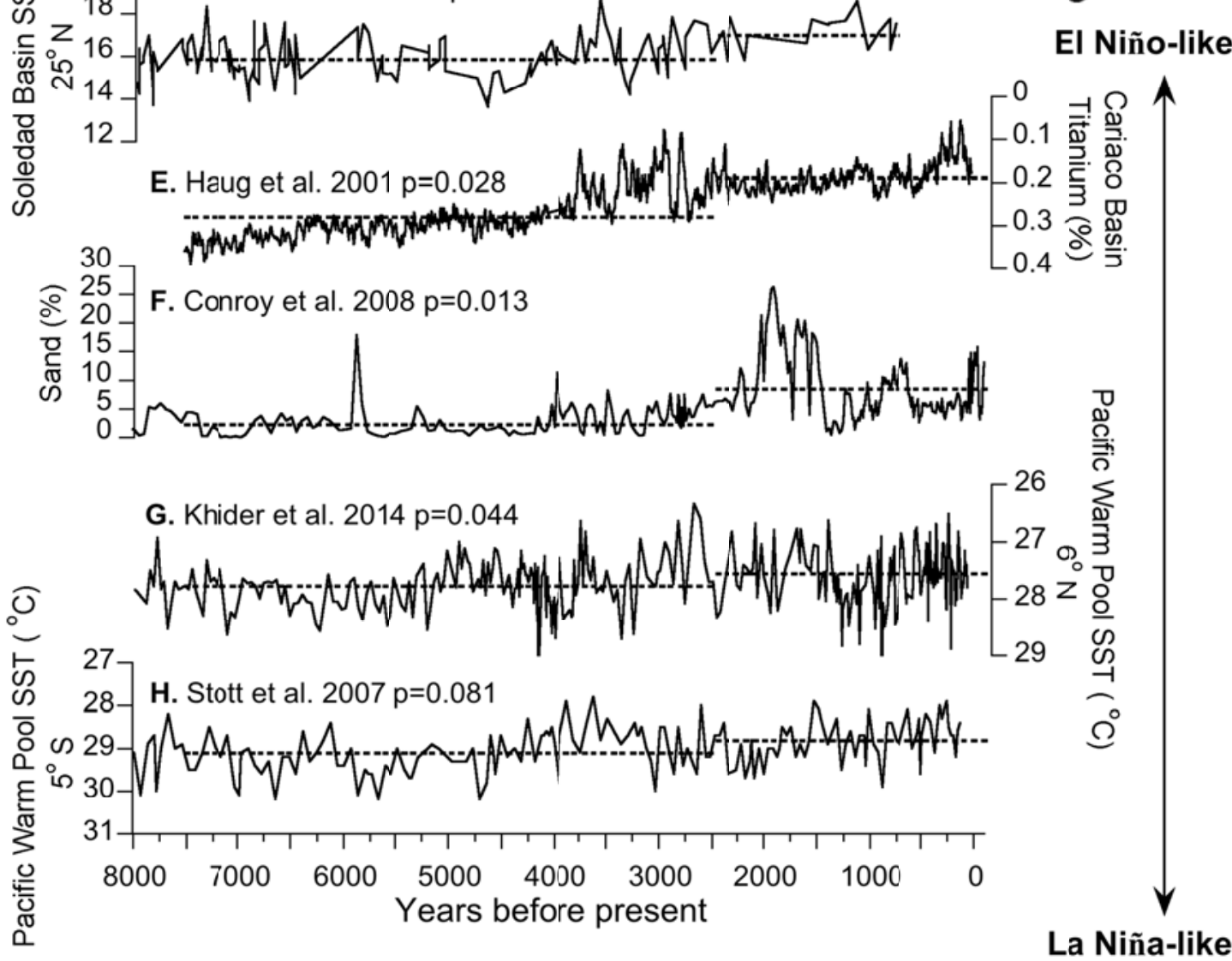

Figure 8. Global proxy record comparison. A) Ice-rafted debris proxy of Arctic Oscillation / Northern Annular Mode variability (Darby et al., 2012). (B) The Paradise and (C) Cleland Lake $\delta^{18} \mathrm{O}$ records. (D) Soledad Basin (eastern tropical Pacific) sea surface temperature (SST) reconstruction; warmer temperatures indicate more El Niño-like conditions (Marchitto et al., 2010). (E) Cariaco Basin titanium (Ti) record of Inter-tropical Convergence Zone (ITCZ) variability; higher Ti values indicate a more northerly position of the ITCZ (Haug et al., 2001). 
1117 (F) The El Junco \% sand record; higher sand fluxes occur during storm events that are enhanced 1118 during more El Niño-like conditions. (G,H) Sea surface temperature (SST) reconstructions from 1119 the Pacific warm pool; more El Niño-like conditions are associated with a cooler western tropical 1120 Pacific Ocean (Khider et al., 2014; Stott et al., 2004). Dashed lines depict mean values during the 1121 middle and late Holocene, with p-values indicating the statistical significance of the difference in 1122 mean values between the two time periods (see Table 1 for additional detail). 

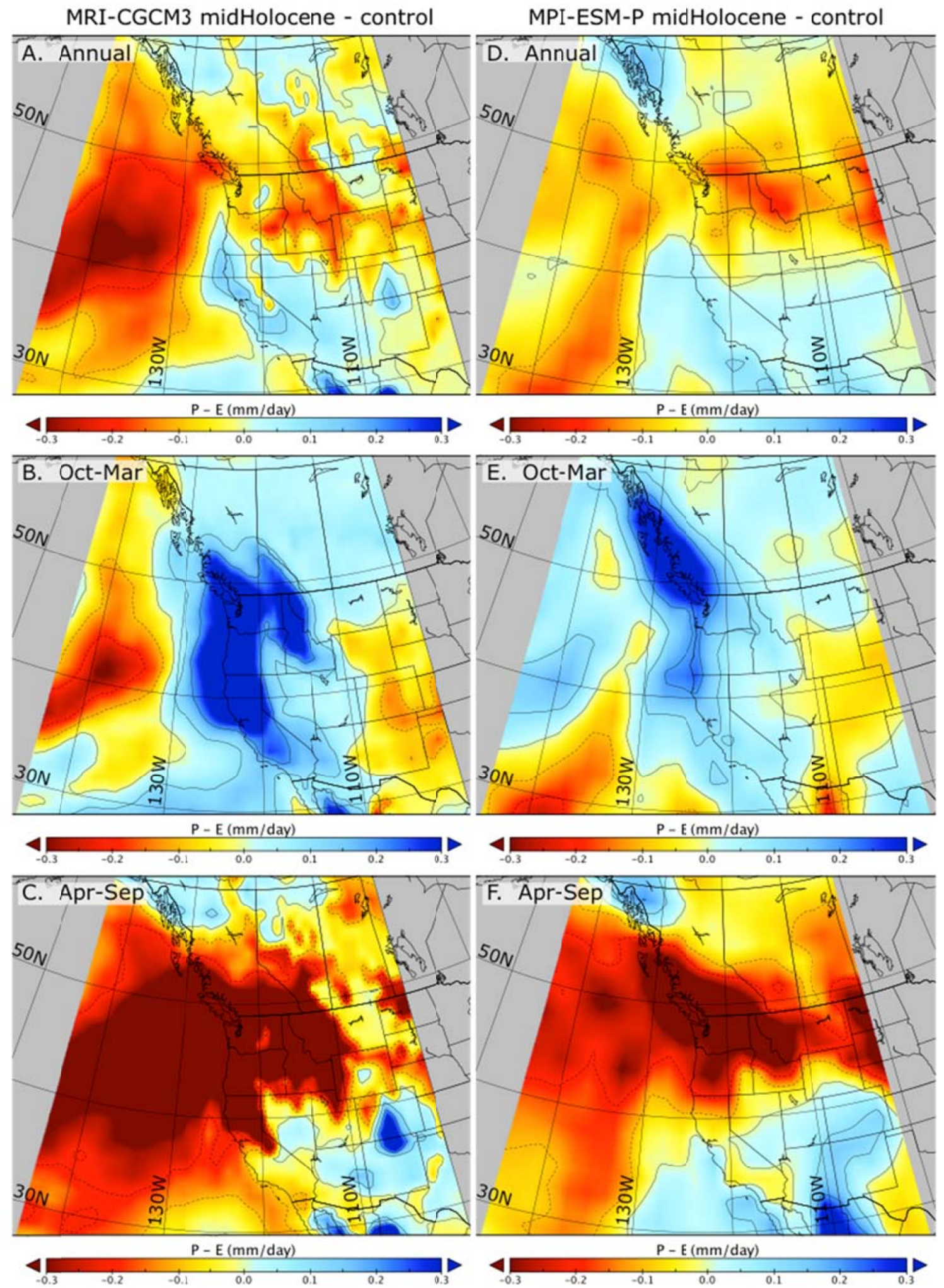

1123

1124

1125

1126
Figure 9. Results from mid-Holocene climate model simulations of precipitation-evaporation balance (i.e., precipitation minus evaporation). Anomalies ( $\mathrm{mm} /$ day) were calculated as the difference between the mid-Holocene (6,000 yr BP) and preindustrial control (AD 1850) 
1127 simulations. A) Annual, B) cold season (October-March), and C) warm season (April-

1128 September) anomalies from MRI-CGCM3. D) Annual, E) cold season (October-March), and F)

1129 warm season (April-September) anomalies from MPI-ESM-P.

1130

1131

1132

1133

1134

1135

1136

1137

1138

1139

1140

1141

1142

1143

1144

1145

1146

1147

1148

1149

1150

1151

1152

1153

1154

1155

1156

1157 
Abbott, M.B., Stafford Jr., T.W., 1996. Radiocarbon Geochemistry of Modern and Ancient Arctic Lake Systems, Baffin Island, Canada. Quat. Res. 45, 300-311. doi:10.1006/qres.1996.0031

Addison, J.A., Finney, B.P., Dean, W.E., Davies, M.H., Mix, A.C., Stoner, J.S., Jaeger, J.M., 2012. Productivity and sedimentary $\delta 15 \mathrm{~N}$ variability for the last 17,000 years along the northern Gulf of Alaska continental slope. Paleoceanography 27. doi:10.1029/2011PA002161

Alexander, M.A., Bladé, I., Newman, M., Lanzante, J.R., Lau, N.-C., Scott, J.D., 2002. The Atmospheric Bridge: The Influence of ENSO Teleconnections on Air-Sea Interaction over the Global Oceans. J. Clim. 15, 2205-2231. doi:10.1175/15200442(2002)015<2205:TABTIO >2.0.CO;2

An, S.-I., 2011. Atmospheric Responses of Gill-Type and Lindzen-Nigam Models to Global Warming. J. Clim. 24, 6165-6173. doi:10.1175/2011JCLI3971.1

An, S.-I., Choi, J., 2014. Mid-Holocene tropical Pacific climate state, annual cycle, and ENSO in PMIP2 and PMIP3. Clim. Dyn. 43, 957-970.

Anderson, L., 2012. Rocky Mountain hydroclimate: Holocene variability and the role of insolation, ENSO, and the North American Monsoon. Glob. Planet. Change 92-93, 198208. doi:10.1016/j.gloplacha.2012.05.012

Anderson, L., 2011. Holocene record of precipitation seasonality from lake calcite $\delta 18 \mathrm{O}$ in the central Rocky Mountains, United States. Geology 39, 211-214. doi:10.1130/G31575.1

Anderson, L., Abbott, M.B., Finney, B.P., Burns, S.J., 2007. Late Holocene moisture balance variability in the southwest Yukon Territory, Canada. Quat. Sci. Rev. 26, 130-141. doi:10.1016/j.quascirev.2006.04.011

Anderson, L., Abbott, M.B., Finney, B.P., Burns, S.J., 2005. Regional atmospheric circulation change in the North Pacific during the Holocene inferred from lacustrine carbonate oxygen isotopes, Yukon Territory, Canada. Quat. Res. 64, 21-35. doi:10.1016/j.yqres.2005.03.005

Appleby, P.G., Oldfield, F., 1978. The calculation of lead-210 dates assuming a constant rate of supply of unsupported $210 \mathrm{~Pb}$ to the sediment. CATENA 5, 1-8. doi:10.1016/S03418162(78)80002-2

Araguás-Araguás, L., Froehlich, K., Rozanski, K., 2000. Deuterium and oxygen-18 isotope composition of precipitation and atmospheric moisture. Hydrol. Process. 14, 1341-1355. doi:10.1002/1099-1085(20000615)14:8<1341::AID-HYP983>3.0.CO;2-Z

Asmerom, Y., Polyak, V., Burns, S., Rassmssen, J., 2007. Solar forcing of Holocene climate: New insights from a speleothem record, southwestern United States. Geology 35, 1-4. doi:10.1130/G22865A.1

Baker, R.G., 1976. Late Quaternary vegetation history of the Yellowstone Lake basin, Wyoming. Geol. Surv. Prof. Pap. 729-E, E1-E48.

Barlow, M., Nigam, S., Berbery, E.H., 2001. ENSO, Pacific Decadal Variability, and U.S. Summertime Precipitation, Drought, and Stream Flow. J. Clim. 14, 2105-2128. doi:10.1175/1520-0442(2001)014<2105:EPDVAU>2.0.CO;2 
Barron, J.A., Anderson, L., 2011. Enhanced Late Holocene ENSO/PDO expression along the margins of the eastern North Pacific. Quat. Int. 235, 3-12. doi:10.1016/j.quaint.2010.02.026

Barron, J.A., Bukry, D., Dean, W.E., Addison, J.A., Finney, B., 2009. Paleoceanography of the Gulf of Alaska during the past 15,000 years: Results from diatoms, silicoflagellates, and geochemistry. Mar. Micropaleontol. 72, 176-195. doi:10.1016/j.marmicro.2009.04.006

Bartlein, P.J., Anderson, K.H., Anderson, P.M., Edwards, M.E., Mock, C.J., Thompson, R.S., Webb, R.S., Webb, T., Whitlock, C., 1998. Paleoclimate simulations for North America over the past 21,000 years: Features of the simulated climate and comparisons with paleoenvironmental data. Quat. Sci. Rev. 17, 549-585. doi:10.1016/S0277-3791(98)000122

Bartlein, P.J., Hostetler, S.W., Alder, J.R., 2014. Paleoclimate, in: Ohring, G. (Ed.), Climate Change in North America, Regional Climate Studies. Springer International Publishing, Cham Heidelberg New York Dordrecht London, pp. 1-51. doi:10.1007/978-3-319-03768-4

Beiswenger, J.M., 1991. Late Quaternary Vegetational History of Grays Lake, Idaho. Ecol. Monogr. 61, 165-182.

Bennett, J.R., Cumming, B.F., Leavitt, P.R., Chiu, M., Smol, J.P., Szeicz, J., 2001. Diatom, pollen, and chemical evidence of postglacial climatic change at Big Lake, south-central British Columbia, Canada. Quat. Res. 55, 332-343. doi:10.1006/qres.2001.2227

Benson, L., Paillet, F., 2002. HIBAL: A hydrologic-isotopic-balance model for application to paleolake systems. Quat. Sci. Rev. 21, 1521-1539. doi:10.1016/S0277-3791(01)00094-4

Benson, L., White, L.D., Rye, R., 1996. Carbonate deposition, Pyramid Lake Subbasin, Nevada: 4. Comparison of the stable isotope values of carbonate deposits (tufas) and the Lahontan lake-level record. Palaeogeogr. Palaeoclimatol. Palaeoecol. 122, 45-76. doi:10.1016/00310182(95)00099-2

Berger, A., 1978. Long-Term Variations of Daily Insolation and Quaternary Climatic Changes. J. Atmos. Sci. 35, 2362-2367. doi:10.1175/1520-0469(1978)035<2362:LTVODI $>2.0 . C O ; 2$

Binford, M.W., 1990. Calculation and uncertainty analysis of $210 \mathrm{~Pb}$ dates for PIRLA project lake sediment cores. J. Paleolimnol. 3, 253-267. doi:10.1007/BF00219461

Biondi, F., Gershunov, A., Cayan, D.R., 2001. North Pacific Decadal Climate Variability since 1661. J. Clim. 14, 5-10. doi:10.1175/1520-0442(2001)014<0005:NPDCVS>2.0.CO;2

Bird, B.W., Kirby, M.E., 2006. An alpine lacustrine record of early Holocene North American Monsoon dynamics from Dry Lake, southern California (USA). J. Paleolimnol. 35, 179192. doi:10.1007/s10933-005-8514-3

Bird, B.W., Kirby, M.E., Howat, I.M., Tulaczyk, S., 2010. Geophysical evidence for Holocene lake-level change in southern California (Dry Lake). Boreas 39, 131-144. doi:10.1111/j.1502-3885.2009.00114.x

Blaauw, M., 2010. Methods and code for "classical" age-modelling of radiocarbon sequences. Quat. Geochronol. 5, 512-518. doi:10.1016/j.quageo.2010.01.002

Bond, N.A., Harrison, D.E., 2000. The Pacific Decadal Oscillation, air-sea interaction and central north Pacific winter atmospheric regimes. Geophys. Res. Lett. 27, 731-734. doi:10.1029/1999GL010847 
Bowen, G.J., Revenaugh, J., 2003. Interpolating the isotopic composition of modern meteoric precipitation. Water Resour. Res. 39, 1299. doi:10.1029/2003WR002086

Braconnot, P., Harrison, S.P., Kageyama, M., Bartlein, P.J., Masson-Delmotte, V., Abe-Ouchi, A., Otto-Bliesner, B., Zhao, Y., 2012. Evaluation of climate models using palaeoclimatic data. Nat. Clim. Chang. 2, 417-424. doi:10.1038/nclimate1456

Braconnot, P., Luan, Y., Brewer, S., Zheng, W., 2011. Impact of Earth's orbit and freshwater fluxes on Holocene climate mean seasonal cycle and ENSO characteristics. Clim. Dyn. 38, 1081-1092. doi:10.1007/s00382-011-1029-x

Braconnot, P., Otto-Bliesner, B., Harrison, S., Joussaume, S., Peterchmitt, J.-Y., Abe-Ouchi, A., Crucifix, M., Driesschaert, E., Fichefet, T., Hewitt, C.D., Kageyama, M., Kitoh, A., Laîné, A., Loutre, M.-F., Marti, O., Merkel, U., Ramstein, G., Valdes, P., Weber, S.L., Yu, Y., Zhao, Y., 2007. Results of PMIP2 coupled simulations of the Mid-Holocene and Last Glacial Maximum - Part 1: experiments and large-scale features. Clim. Past 3, 261-277. doi:10.5194/cp-3-261-2007

Braconnot, P., Otto-Bliesner, B., Harrison, S., Joussaume, S., Peterchmitt, J.-Y., Abe-Ouchi, A., Crucifix, M., Fichefet, T., Hewitt, C.D., Kageyama, M., Kitoh, A., Loutre, M.-F., Marti, O., Merkel, U., Ramstein, G., Valdes, P., Weber, L., Yu, Y., Zhao, Y., 2006. Coupled simulations of the mid-Holocene and Last Glacial Maximum: new results from PMIP2. Clim. Past Discuss. 2, 1293-1346. doi:10.5194/cpd-2-1293-2006

Brown, D.P., Comrie, A.C., 2004. A winter precipitation "dipole" in the western United States associated with multidecadal ENSO variability. Geophys. Res. Lett. 31. doi:10.1029/2003GL018726

Brown, J., Tudhope, A.W., Collins, M., McGregor, H. V., 2008. Mid-Holocene ENSO: Issues in quantitative model-proxy data comparisons. Paleoceanography 23. doi:10.1029/2007PA001512

Brunelle, A., Whitlock, C., 2003. Postglacial fire, vegetation, and climate history in the Clearwater Range, Northern Idaho, USA. Quat. Res. 60, 307-318. doi:10.1016/j.yqres.2003.07.009

Calder, I., Hall, R., Bastable, H., Gunston, H., Shela, O., Chirwa, A., Kafundu, R., 1995. The impact of land use change on water resources in sub-Saharan Africa: a modelling study of Lake Malawi. J. Hydrol. 170, 123-135. doi:10.1016/0022-1694(94)02679-6

Cayan, D.R., Dettinger, M.D., Diaz, H.F., Graham, N.E., 1998. Decadal Variability of Precipitation over Western North America. J. Clim. 11, 3148-3166. doi:10.1175/15200442(1998)011<3148:DVOPOW>2.0.CO;2

Cayan, D.R., Redmond, K.T., Riddle, L.G., 1999. ENSO and Hydrologic Extremes in the Western United States. J. Clim. 12, 2881-2893. doi:10.1175/15200442(1999)012<2881:EAHEIT>2.0.CO;2

Chase, M., Bleskie, C., Walker, I.R., Gavin, D.G., Hu, F.S., 2008. Midge-inferred Holocene summer temperatures in Southeastern British Columbia, Canada. Palaeogeogr. Palaeoclimatol. Palaeoecol. 257, 244-259. doi:10.1016/j.palaeo.2007.10.020

Chiang, J.C.H., Fang, Y., Chang, P., 2009. Pacific Climate Change and ENSO Activity in the Mid-Holocene. J. Clim. 22, 923-939. doi:10.1175/2008JCLI2644.1 
Clement, A.C., Cane, M.A., Seager, R., 2001. An Orbitally Driven Tropical Source for Abrupt Climate Change. J. Clim. 14, 2369-2375. doi:10.1175/15200442(2001)014<2369:AODTSF>2.0.CO;2

Clement, A.C., Seager, R., Cane, M.A., 2000. Suppression of E1 Niño during the Mid-Holocene by changes in the Earth's orbit. Paleoceanography 15, 731-737. doi:10.1029/1999PA000466

Cobb, K.M., Westphal, N., Sayani, H.R., Watson, J.T., Di Lorenzo, E., Cheng, H., Edwards, R.L., Charles, C.D., 2013. Highly variable El Niño-Southern Oscillation throughout the Holocene. Science 339, 67-70. doi:10.1126/science.1228246

Compo, G.P., Whitaker, J.S., Sardeshmukh, P.D., Matsui, N., Allan, R.J., Yin, X., Gleason, B.E., Vose, R.S., Rutledge, G., Bessemoulin, P., Brönnimann, S., Brunet, M., Crouthamel, R.I., Grant, A.N., Groisman, P.Y., Jones, P.D., Kruk, M.C., Kruger, A.C., Marshall, G.J., Maugeri, M., Mok, H.Y., Nordli, Ø., Ross, T.F., Trigo, R.M., Wang, X.L., Woodruff, S.D., Worley, S.J., 2011. The Twentieth Century Reanalysis Project. Q. J. R. Meteorol. Soc. 137, 1-28. doi:10.1002/qj.776

Conroy, J.L., Overpeck, J.T., Cole, J.E., Shanahan, T.M., Steinitz-Kannan, M., 2008. Holocene changes in eastern tropical Pacific climate inferred from a Galápagos lake sediment record. Quat. Sci. Rev. 27, 1166-1180. doi:10.1016/j.quascirev.2008.02.015

Craig, H., Gordon, L.I., 1965. Deuterium and oxygen-18 variations in the ocean and marine atmospheres, in: Tongiorgi, E. (Ed.), Proceedings of a Conference on Stable Isotopes in Oceanographic Studies and Palaeotemperatures. Pisa, Italy, pp. 9-130.

Darby, D. a, Ortiz, J.D., Grosch, C.E., Lund, S.P., 2012. 1,500-year cycle in the Arctic Oscillation identified in Holocene Arctic sea-ice drift. Nat. Geosci. 5, 897-900. doi:10.1038/ngeo1629

Dettinger, M.D., Cayan, D.R., Diaz, H.F., Meko, D.M., 1998. North-South Precipitation Patterns in Western North America on Interannual-to-Decadal Timescales. J. Clim. 11, 3095-3111. doi:10.1175/1520-0442(1998)011<3095:NSPPIW>2.0.CO;2

Di Lorenzo, E., Cobb, K.M., Furtado, J.C., Schneider, N., Anderson, B.T., Bracco, A., Alexander, M.A., Vimont, D.J., 2010. Central Pacific El Niño and decadal climate change in the North Pacific Ocean. Nat. Geosci. 3, 762-765. doi:10.1038/ngeo984

Diffenbaugh, N.S., Ashfaq, M., Shuman, B., Williams, J.W., Bartlein, P.J., 2006. Summer aridity in the United States: Response to mid-Holocene changes in insolation and sea surface temperature. Geophys. Res. Lett. 33. doi:10.1029/2006GL028012

Diffenbaugh, N.S., Sloan, L.C., 2004. Mid-Holocene Orbital Forcing of Regional-Scale Climate: A Case Study of Western North America Using a High-Resolution RCM. J. Clim. 17, 2927-2937. doi:10.1175/1520-0442(2004)017<2927:MOFORC>2.0.CO;2

Dinçer, T., 1968. The Use of Oxygen 18 and Deuterium Concentrations in the Water Balance of Lakes. Water Resour. Res. 4, 1289. doi:10.1029/WR004i006p01289

Doerner, J.P., Carrara, P.E., 2001. Late quaternary vegetation and climatic history of the long valley area, west-Central idaho, u.s.a. Quat. Res. 56, 103-111. doi:10.1006/qres.2001.2247

Donders, T.H., Wagner, F., Dilcher, D.L., Visscher, H., 2005. Mid- to late-Holocene El NiñoSouthern Oscillation dynamics reflected in the subtropical terrestrial realm. Proc. Natl. 
Acad. Sci. U. S. A. 102, 10904-10908. doi:10.1073/pnas.0505015102

Donders, T.H., Wagner-Cremer, F., Visscher, H., 2008. Integration of proxy data and model scenarios for the mid-Holocene onset of modern ENSO variability. Quat. Sci. Rev. 27, 571579. doi:10.1016/j.quascirev.2007.11.010

Dong, B., Sutton, R.T., Scaife, A.A., 2006. Multidecadal modulation of El Niño-Southern Oscillation (ENSO) variance by Atlantic Ocean sea surface temperatures. Geophys. Res. Lett. 33, L08705. doi:10.1029/2006GL025766

Donovan, J.J., Smith, A.J., Panek, V.A., Engstrom, D.R., Ito, E., 2002. Climate-driven hydrologic transients in lake sediment records: Multiproxy record of mid-Holocene drought. Quat. Sci. Rev. 21, 625-646. doi:10.1016/S0277-3791(01)00041-5

Drummond, C.N., Patterson, W.P., Walker, J.C.G., 1995. Climate forcing of carbon-oxygen isotopic covariance in temperate- region marl lakes. Geology. doi:10.1130/00917613(1995)023<1031:CFOCOI $>2.3 . \mathrm{CO}$

Emile-Geay, J., Cane, M., Seager, R., Kaplan, A., Almasi, P., 2007. El Niño as a mediator of the solar influence on climate. Paleoceanography 22, 16. doi:Artn Pa3210 \rDoi 10.1029/2006pa001304

Enfield, D.B., Mestas-Nuñez, A.M., Trimble, P.J., 2001. The Atlantic multidecadal oscillation and its relation to rainfall and river flows in the continental U.S. Geophys. Res. Lett. 28, 2077-2080. doi:10.1029/2000GL012745

Ersek, V., Clark, P.U., Mix, A.C., Cheng, H., Edwards, R.L., 2012. Holocene winter climate variability in mid-latitude western North America. Nat. Commun. 3, 1219. doi: $10.1038 /$ ncomms 2222

Feng, S., Oglesby, R.J., Rowe, C.M., Loope, D.B., Hu, Q., 2008. Atlantic and Pacific SST influences of medieval drought in North America simulated by the Community Atmospheric Model. J. Geophys. Res. D Atmos. 113. doi:10.1029/2007JD009347

Fisher, D., Osterberg, E., Dyke, A., Dahl-Jensen, D., Demuth, M., Zdanowicz, C., Bourgeois, J., Koerner, R.M., Mayewski, P., Wake, C., Kreutz, K., Steig, E., Zheng, J., Yalcin, K., GotoAzuma, K., Luckman, B., Rupper, S., 2008. The Mt Logan Holocene - late Wisconsinan isotope record: tropical Pacific - Yukon connections. The Holocene 18, 667-677. doi: $10.1177 / 0959683608092236$

Galloway, J.M., Lenny, A.M., Cumming, B.F., 2011. Hydrological change in the central interior of British Columbia, Canada: Diatom and pollen evidence of millennial-to-centennial scale change over the Holocene. J. Paleolimnol. 45, 183-197. doi:10.1007/s10933-010-9490-9

Gat, J.R., 1995. Stable Isotopes of Fresh and Saline Lakes, in: Lerman, A., Imboden, D.M., Gat, J.R. (Eds.), Physics and Chemistry of Lakes. Springer Berlin Heidelberg, pp. 139-165.

Gat, J.R., 1981. Stable Isotope Hydrology: Deuterium and Oxygen-18 in the Water Cycle, in: Gat, J.R., Gonfiantini, R. (Eds.), I.A.E.A. Technical Report 210. Viena, pp. 203-221.

Gat, J.R., 1970. Environmental isotopes balance of Lake Tiberias. Int. At. Energy Agency 109129.

Ge, Y., Gong, G., Frei, A., 2009. Physical Mechanisms Linking the Winter Pacific-North American Teleconnection Pattern to Spring North American Snow Depth. J. Clim. 22, 
Gedalof, Z., 2002. A multi-century perspective of variability in the Pacific Decadal Oscillation: new insights from tree rings and coral. Geophys. Res. Lett. 29. doi:10.1029/2002GL015824

1368

1369

1370

1371

1372

1373

1374

1375

1376

1377

1378

1379

1380

1381

1382

1383

1384

1385

1386

1387

1388

1389

1390

1391

1392

1393

1394

1395

1396

1397

1398

1399

1400

1401

1402

1403

1404

1405

Gibson, J.J., 2002. Short-term evaporation and water budget comparisons in shallow Arctic lakes using non-steady isotope mass balance. J. Hydrol. 264, 242-261. doi:10.1016/S00221694(02)00091-4

Gibson, J.J., Birks, S.J., Yi, Y., 2015. Stable isotope mass balance of lakes: a contemporary perspective. Quat. Sci. Rev. doi:10.1016/j.quascirev.2015.04.013

Gibson, J.J., Edwards, T.W.D., Prowse, T.D., 1996. Development and validation of an isotopic method for estimating lake evaporation. Hydrol. Process. 10, 1369-1382. doi:10.1002/(SICI)1099-1085(199610)10:10<1369::AID-HYP467>3.0.CO;2-J

Gibson, J.J., Prepas, E.E., McEachern, P., 2002. Quantitative comparison of lake throughflow, residency, and catchment runoff using stable isotopes: Modelling and results from a regional survey of Boreal lakes. J. Hydrol. 262, 128-144. doi:10.1016/S00221694(02)00022-7

Gonfiantini, R., 1986. Environmental isotopes in lake studies, in: Fritz, P., Fontes, J.C. (Eds.), Handbook of Environmental Geochemistry, Vol. 2: The Terrestrial Environment. B. Elsevier Science, pp. 113-168.

Hallett, D.J., Hills, L. V., 2006. Holocene vegetation dynamics, fire history, lake level and climate change in the Kootenay Valley, southeastern British Columbia, Canada. J. Paleolimnol. 35, 351-371. doi:10.1007/s10933-005-1335-6

Hallett, D.J., Hills, L. V., Clague, J.J., 1997. New accelerator mass spectrometry radiocarbon ages for the Mazama tephra layer from Kootenay National Park, British Columbia, Canada. Can. J. Earth Sci. 34, 1202-1209. doi:10.1139/e17-096

Hare, S.R., Mantua, N.J., 2001. An historical narrative on the Pacific Decadal Oscillation, interdecadal climate variability and ecosystem impacts, in: 20th NE Pacific Pink and Chum Workshop. p. 19.

Harrison, S., Kutzbach, J., Liu, Z., Bartlein, P., 2003. Mid-Holocene climates of the Americas: a dynamical response to changed seasonality. Clim. Dyn. 20, 663-688. doi:10.1007/s00382002-0300-6

Harrison, S.P., Bartlein, P.J., Brewer, S., Prentice, I.C., Boyd, M., Hessler, I., Holmgren, K., Izumi, K., Willis, K., 2014. Climate model benchmarking with glacial and mid-Holocene climates. Clim. Dyn. 43, 671-688. doi:10.1007/s00382-013-1922-6

Harrison, S.P., Bartlein, P.J., Izumi, K., Li, G., Annan, J., Hargreaves, J., Braconnot, P., Kageyama, M., 2015. Evaluation of CMIP5 palaeo-simulations to improve climate projections. Nat. Clim. Chang. 5, 735-743. doi:10.1038/nclimate2649

Hastenrath, S., Kutzbach, J.E., 1983. Paleoclimatic estimates from water and energy budgets of East African Lakes. Quat. Res. 19, 141-153. doi:10.1016/0033-5894(83)90001-7

Haug, G.H., Hughen, K.A., Sigman, D.M., Peterson, L.C., Röhl, U., 2001. Southward migration of the intertropical convergence zone through the Holocene. Science 293, 1304-1308. doi:10.1126/science. 1059725 
1406

1407

1408

1409

1410

1411

1412

1413

1414

1415

1416

1417

1418

1419

1420

1421

1422

1423

1424

1425

1426

1427

1428

1429

1430

1431

1432

1433

1434

1435

1436

1437

1438

1439

1440

1441

1442

1443

1444

1445

1446

Hebda, R.J., 1995. British Columbia Vegetation and Climate History with Focus on 6 ka BP. Géographie Phys. Quat. 49, 66-79. doi:10.7202/033030ar

Heinrichs, M.L., Hebda, R.J., Walker, I.R., 2001. Holocene vegetation and natural disturbance in the Engelmann Spruce - Subalpine Fir biogeoclimatic zone at Mount Kobau, British Columbia. Can. J. For. Res. 31, 2183-2199. doi:10.1139/x01-157

Heinrichs, M.L., Hebda, R.J., Walker, I.R., Palmer, S.L., 2002. Postglacial paleoecology and inferred paleoclimate in the Engelmann spruce-subalpine fir forest of south-central British Columbia, Canada. Palaeogeogr. Palaeoclimatol. Palaeoecol. 184, 347-369. doi:10.1016/S0031-0182(02)00274-2

Heinrichs, M.L., Walker, I.R., Mathewes, R.W., Hebda, R.J., 1999. Holocene chironomidinferred salinity and paleovegetation reconstruction from Kilpoola Lake, British Columbia. Géographie Phys. Quat. 53, 211-221. doi:10.7202/004878ar

Hidalgo, H.G., 2004. Climate precursors of multidecadal drought variability in the western United States. Water Resour. Res. 40, 1-10. doi:10.1029/2004WR003350

Hodell, D.A., Schelske, C.L., Fahnenstiel, G.L., Robbins, L.L., 1998. Biologically induced calcite and its isotopic composition in Lake Ontario. Limnol. Oceanogr. 43, 187-199. doi:10.4319/1o.1998.43.2.0187

Hoelzmann, P., Kruse, H.J., Rottinger, F., 2000. Precipitation estimates for the eastern Saharan palaeomonsoon based on a water balance model of the West Nubian Palaeolake Basin. Glob. Planet. Change 26, 105-120. doi:10.1016/S0921-8181(00)00038-2

Holmgren, C.A., Betancourt, J.L., Rylander, K.A., 2010. A long-term vegetation history of the mojave-colorado desert ecotone at joshua tree national park. J. Quat. Sci. 25, 222-236. doi:10.1002/jqs. 1313

Holmgren, C.A., Betancourt, J.L., Rylander, K.A., 2006. A 36,000-yr vegetation history from the Peloncillo Mountains, southeastern Arizona, USA. Palaeogeogr. Palaeoclimatol. Palaeoecol. 240, 405-422. doi:10.1016/j.palaeo.2006.02.017

Horita, J., Wesolowski, D.J., 1994. Liquid-vapor fractionation of oxygen and hydrogen isotopes of water from the freezing to the critical temperature. Geochim. Cosmochim. Acta 58, 3425-3437. doi:10.1016/0016-7037(94)90096-5

Horton, T.W., Defliese, W.F., Tripati, A.K., Oze, C., 2016. Evaporation induced 180 and 13C enrichment in lake systems: A global perspective on hydrologic balance effects. Quat. Sci. Rev. 131, 365-379. doi:10.1016/j.quascirev.2015.06.030

Hostetler, S.W., Benson, L. V., 1994. Stable isotopes of oxygen and hydrogen in the Truckee River-Pyramid Lake surface-water system, 2. A predictive model of $\delta 18 \mathrm{O}$ and $\delta 2 \mathrm{H}$ in Pyramid Lake. Limnol. Oceanogr. 39, 356-364.

Huerta, M.A., Whitlock, C., Yale, J., 2009. Holocene vegetation-fire-climate linkages in northern Yellowstone National Park, USA. Palaeogeogr. Palaeoclimatol. Palaeoecol. 271, 170-181. doi:10.1016/j.palaeo.2008.10.015

Jiménez-Moreno, G., Fawcett, P.J., Scott Anderson, R., 2008. Millennial- and centennial-scale vegetation and climate changes during the late Pleistocene and Holocene from northern New Mexico (USA). Quat. Sci. Rev. 27, 1442-1452. doi:10.1016/j.quascirev.2008.04.004 
Jones, M.D., Imbers, J., 2010. Modeling Mediterranean lake isotope variability. Glob. Planet. Change 71, 193-200. doi:10.1016/j.gloplacha.2009.10.001

Jones, M.D., Leng, M.J., Roberts, C.N., Türkeş, M., Moyeed, R., 2005. A Coupled Calibration and Modelling Approach to the Understanding of Dry-Land Lake Oxygen Isotope Records. J. Paleolimnol. 34, 391-411. doi:10.1007/s10933-005-6743-0

Jones, M.D., Metcalfe, S.E., Davies, S.J., Noren, A., 2015. Late Holocene climate reorganisation and the North American Monsoon. Quat. Sci. Rev. 124, 290-295. doi:10.1016/j.quascirev.2015.07.004

Jones, M.D., Roberts, C.N., Leng, M.J., 2007. Quantifying climatic change through the last glacial-interglacial transition based on lake isotope palaeohydrology from central Turkey. Quat. Res. 67, 463-473. doi:10.1016/j.yqres.2007.01.004

Jones, M.D., Roberts, N.C., 2008. Interpreting lake isotope records of Holocene environmental change in the Eastern Mediterranean. Quat. Int. 181, 32-38. doi:10.1016/j.quaint.2007.01.012

Jungclaus, J.H., Fischer, N., Haak, H., Lohmann, K., Marotzke, J., Matei, D., Mikolajewicz, U., Notz, D., Von Storch, J.S., 2013. Characteristics of the ocean simulations in the Max Planck Institute Ocean Model (MPIOM) the ocean component of the MPI-Earth system model. J. Adv. Model. Earth Syst. 5, 422-446. doi:10.1002/jame.20023

Kelts, K., Hsu, K.J., 1978. Freshwater Carbonate Sedimentation, in: Lerman, A. (Ed.), Lakes: Chemistry, Geology, Physics. Springer-Verlag Berlin Heidelberg, Berlin, pp. 295-323.

Khider, D., Jackson, C.S., Stott, L.D., 2014. Assessing millennial-scale variability during the Holocene: A perspective from the western tropical Pacific. Paleoceanography 29, 143-159. doi:10.1002/2013PA002534

Kim, J.-H., Rimbu, N., Lorenz, S.J., Lohmann, G., Nam, S.-I., Schouten, S., Rühlemann, C., Schneider, R.R., 2004. North Pacific and North Atlantic sea-surface temperature variability during the Holocene. Quat. Sci. Rev. 23, 2141-2154. doi:10.1016/j.quascirev.2004.08.010

Kim, S.-T., O’Neil, J.R., 1997. Equilibrium and nonequilibrium oxygen isotope effects in synthetic carbonates. Geochim. Cosmochim. Acta. doi:10.1016/S0016-7037(97)00169-5

Kim, S.T., O’Neil, J.R., Hillaire-Marcel, C., Mucci, A., 2007. Oxygen isotope fractionation between synthetic aragonite and water: Influence of temperature and $\mathrm{Mg} 2+$ concentration. Geochim. Cosmochim. Acta 71, 4704-4715. doi:10.1016/j.gca.2007.04.019

Kirby, M.E., Feakins, S.J., Bonuso, N., Fantozzi, J.M., Hiner, C.A., 2013. Latest Pleistocene to Holocene hydroclimates from Lake Elsinore, California. Quat. Sci. Rev. doi:10.1016/j.quascirev.2013.05.023

Kirby, M.E., Knell, E.J., Anderson, W.T., Lachniet, M.S., Palermo, J., Eeg, H., Lucero, R., Murrieta, R., Arevalo, A., Silveira, E., Hiner, C.A., 2015. Evidence for insolation and Pacific forcing of late glacial through Holocene climate in the Central Mojave Desert (Silver Lake, CA). Quat. Res. 84, 174-186. doi:10.1016/j.yqres.2015.07.003

Kirby, M.E., Lund, S.P., Patterson, W.P., Anderson, M.A., Bird, B.W., Ivanovici, L., Monarrez, P., Nielsen, S., 2010. A Holocene record of Pacific Decadal Oscillation (PDO)-related hydrologic variability in Southern California (Lake Elsinore, CA). J. Paleolimnol. 44, 819839. doi:10.1007/s10933-010-9454-0 
Kirby, M.E., Zimmerman, S.R.H., Patterson, W.P., Rivera, J.J., 2012. A 9170-year record of decadal-to-multi-centennial scale pluvial episodes from the coastal Southwest United States: A role for atmospheric rivers? Quat. Sci. Rev. 46, 57-65. doi:10.1016/j.quascirev.2012.05.008

Klenner, W., Walton, R., Arsenault, A., Kremsater, L., 2008. Dry forests in the Southern Interior of British Columbia: Historic disturbances and implications for restoration and management. For. Ecol. Manage. 256, 1711-1722. doi:10.1016/j.foreco.2008.02.047

Koschel, R., Benndorf, J., Proft, G., Recknagel, F., 2011. Calcite precipitation a a natural control mechnism of eutrophication. Arch. fur Hydrobiol. 98, 340-408. doi:10.1007/SpringerReference_205967

Koschel, R.H., 1997. Structure and Function of Pelagic Calcite Precipitation In Lake Ecosystems. Verhandlungen - Int. Vereinigung für Theor. und Angew. Limnol. 26, 343349.

Koutavas, A., DeMenocal, P.B., Olive, G.C., Lynch-Stieglitz, J., 2006. Mid-Holocene El NiñoSouthern Oscillation (ENSO) attenuation revealed by individual foraminifera in eastern tropical Pacific sediments. Geology 34, 993-996. doi:10.1130/G22810A.1

Koutavas, A., Joanides, S., 2012. El Niño-Southern Oscillation extrema in the Holocene and Last Glacial Maximum. Paleoceanography 27, n/a-n/a. doi:10.1029/2012PA002378

Krider, P.R., 1998. Paleoclimatic Significance of Late Quaternary Lacustrine and Alluvial Stratigraphy, Animas Valley, New Mexico. Quat. Res. 50, 283-289. doi:10.1006/qres.1998.1997

Kutzbach, J., Gallimore, R., Harrison, S., Behling, P., Selin, R., Laarif, F., 1998. Climate and Biome simulations for the past 21,000 years. Quat. Sci. Rev. 17, 473-506. doi:10.1016/S0277-3791(98)00009-2

Kutzbach, J.E., Guetter, P.J., Behling, P.J., Selin, R., 1993. Simulated Climatic Changes: Results of the COHMAP Climate-Model Experiments, in: Wright Jr., H.E., Kutzbach, J.E., Webb III, T., Ruddiman, W.F., Street- Perrott, F.A., Bartlein, P.J. (Eds.), Global Climates since the Last Glacial Maximum. University of Minnesota Press, Minneapolis, pp. 468-512.

Lachniet, M.S., Denniston, R.F., Asmerom, Y., Polyak, V.J., 2014. Orbital control of western North America atmospheric circulation and climate over two glacial cycles. Nat. Commun. 5, 3805. doi:10.1038/ncomms4805

Leathers, D.J., Palecki, M.A., 1992. The Pacific/North American Teleconnection Pattern and United States Climate. Part II: Temporal Characteristics and Index Specification. J. Clim. 5, 707-716. doi:10.1175/1520-0442(1992)005<0707:TPATPA > 2.0.CO;2

Leathers, D.J., Yarnal, B., Palecki, M.A., 1991. The Pacific North-American Teleconnection Pattern and United-States Climate. Part I: Regional Temperature and Precipitation Associations. J. Clim. 4, 517-528. doi:Doi 10.1175/15200442(1991)004<0517:Tpatpa >2.0.Co;2

Lee, Y.Y., Kug, J.S., Lim, G.H., Watanabe, M., 2012. Eastward shift of the Pacific/North American pattern on an interdecadal time scale and an associated synoptic eddy feedback. Int. J. Climatol. 32, 1128-1134. doi:10.1002/joc.2329

Leng, M.J., Marshall, J.D., 2004. Palaeoclimate interpretation of stable isotope data from lake 
sediment archives. Quat. Sci. Rev. 23, 811-831. doi:10.1016/j.quascirev.2003.06.012

$\mathrm{Li}, \mathrm{H} . \mathrm{C}$., $\mathrm{Ku}, \mathrm{T} . \mathrm{L} ., 1997 . \delta 13 \mathrm{C}-\delta 18 \mathrm{O}$ covariance as a paleohydrological indicator for closedbasin lakes. Palaeogeogr. Palaeoclimatol. Palaeoecol. 133, 69-80. doi:10.1016/S00310182(96)00153-8

Li, H.C., Xu, X.M., Ku, T.L., You, C.F., Buchheim, H.P., Peters, R., 2008. Isotopic and geochemical evidence of palaeoclimate changes in Salton Basin, California, during the past 20??kyr: 1. ??180 and ??13C records in lake tufa deposits. Palaeogeogr. Palaeoclimatol. Palaeoecol. 259, 182-197. doi:10.1016/j.palaeo.2007.10.006

Li, Y., Morrill, C., 2013. Lake levels in Asia at the Last Glacial Maximum as indicators of hydrologic sensitivity to greenhouse gas concentrations. Quat. Sci. Rev. 60, 1-12. doi:10.1016/j.quascirev.2012.10.045

Lima, A.L., Hubeny, J.B., Reddy, C.M., King, J.W., Hughen, K.A., Eglinton, T.I., 2005. Highresolution historical records from Pettaquamscutt River basin sediments: $1.210 \mathrm{~Pb}$ and varve chronologies validate record of $137 \mathrm{Cs}$ released by the Chernobyl accident. Geochim. Cosmochim. Acta 69, 1803-1812. doi:10.1016/j.gca.2004.10.009

Liu, Z., Bowen, G.J., Welker, J.M., Yoshimura, K., 2013. Winter precipitation isotope slopes of the contiguous USA and their relationship to the Pacific/North American (PNA) pattern. Clim. Dyn. 41, 403-420. doi:10.1007/s00382-012-1548-0

Liu, Z., Kennedy, C.D., Bowen, G.J., 2011. Pacific/North American teleconnection controls on precipitation isotope ratios across the contiguous United States. Earth Planet. Sci. Lett. 310, 319-326. doi:10.1016/j.epsl.2011.08.037

Liu, Z., Kutzbach, J., Wu, L., 2000. Modeling climate shift of El Niño variability in the Holocene. Geophys. Res. Lett. 27, 2265-2268. doi:10.1029/2000GL011452

Liu, Z., Yoshimura, K., Bowen, G.J., Buenning, N.H., Risi, C., Welker, J.M., Yuan, F., 2014. Paired oxygen isotope records reveal modern North American atmospheric dynamics during the Holocene. Nat. Commun. 5, 3701. doi:10.1038/ncomms4701

Lowe, D.J., Green, J.D., Northcote, T.G., Hall, K.J., 1997. Holocene Fluctuations of a Meromictic Lake in Southern British Columbia. Quat. Res. 48, 100-113. doi:10.1006/qres.1997.1905

Lyons, R.P., Kroll, C.N., Scholz, C.A., 2011. An energy-balance hydrologic model for the Lake Malawi Rift Basin, East Africa. Glob. Planet. Change 75, 83-97. doi:10.1016/j.gloplacha.2010.10.010

MacDonald, G.M., Case, R.A., 2005. Variations in the Pacific Decadal Oscillation over the past millennium. Geophys. Res. Lett. 32, 1-4. doi:10.1029/2005GL022478

Mack, R.N., Rutter, N.W., Bryant, V.M., Valastro, S., 1978a. Reexamination of postglacial vegetation history in northern Idaho: Hager Pond, Bonner Co. Quat. Res. 10, 241-255. doi:10.1016/0033-5894(78)90104-7

Mack, R.N., Rutter, N.W., Bryant, V.M., Valastro, S., 1978b. Late Quaternary Pollen Record from Big Meadow, Pend Oreille County, Washington. Ecology 59, 956-965. doi: $10.2307 / 1938547$

Mack, R.N., Rutter, N.W., Valastro, S., 1983. Holocene vegetational history of the Kootenai 
River Valley, Montana. Quat. Res. 20, 177-193. doi:10.1016/0033-5894(83)90076-5

1573

1574

1575

1576

1577

1578

1579

1580

1581

1582

1583

1584

1585

1586

1587

1588

1589

1590

1591

1592

1593

1594

1595

1596

1597

1598

1599

1600

1601

1602

1603

1604

1605

1606

1607

1608

1609

1610

1611

1612

Mack, R.N., Rutter, N.W., Valastro, S., 1979. Holocene vegetation history of the Okanogan Valley, Washington. Quat. Res. 12, 212-225. doi:10.1016/0033-5894(79)90058-9

Mack, R.N., Rutter, N.W., Valastro, S., 1978c. Late Quaternary pollen record from the Sanpoil River Valley, Washington. Can. J. Bot. 56, 1642-1650. doi:10.1139/b78-193

Mantua, N.J., Hare, S.R., 2002. The Pacific Decadal Oscillation. J. Oceanogr. 58, 35-44. doi:10.1023/A:1015820616384

Mantua, N.J., Hare, S.R., Zhang, Y., Wallace, J.M., Francis, R.C., 1997. A Pacific Interdecadal Climate Oscillation with Impacts on Salmon Production. Bull. Am. Meteorol. Soc. 78, 1069-1079. doi:10.1175/1520-0477(1997)078<1069:APICOW>2.0.CO;2

Marchant, M., Hebbeln, D., Wefer, G., 1999. High resolution planktic foraminiferal record of the last 13,300 years from the upwelling area off Chile. Mar. Geol. 161, 115-128. doi:10.1016/S0025-3227(99)00041-9

Marchitto, T.M., Muscheler, R., Ortiz, J.D., Carriquiry, J.D., van Geen, A., 2010. Dynamical response of the tropical Pacific Ocean to solar forcing during the early Holocene. Science 330, 1378-1381. doi:10.1126/science.1194887

Markgraf, V., Bradbury, J.P., Forester, R.M., Singh, G., Sternberg, R.S., 1984. San Agustin Plains, New Mexico: Age and paleoenvironmental potential reassessed. Quat. Res. 22, 336343. doi:10.1016/0033-5894(84)90027-9

Mathewes, R.W., 1985. Paleobotanical evidence for climatic change in southern British Columbia during late-glacial and Holocene time, in: Harrington, C.R. (Ed.), Climate Change in Canada 5-Critical Periods in the Quaternary Climatic History of Northern North America. National Museums of Canada, Syllogeus 55, pp. 397-422.

Mathewes, R.W., King, M., 1989. Holocene vegetation, climate, and lake-level changes in the Interior Douglas-fir Biogeoclimatic Zone, British Columbia. Can. J. Earth Sci. 26, 18111825. doi:10.1139/e89-154

McAfee, S.A., Russell, J.L., 2008. Northern annular mode impact on spring climate in the western United States. Geophys. Res. Lett. 35. doi:10.1029/2008GL034828

McAuliffe, J.R., Van Devender, T.R., 1998. A 22,000-year record of vegetation change in the north-central Sonoran Desert. Palaeogeogr. Palaeoclimatol. Palaeoecol. 141, 253-275. doi:10.1016/S0031-0182(98)00054-6

McCabe, G.J., Betancourt, J.L., Gray, S.T., Palecki, M.A., Hidalgo, H.G., 2008. Associations of multi-decadal sea-surface temperature variability with US drought. Quat. Int. 188, 31-40. doi:10.1016/j.quaint.2007.07.001

McCabe, G.J., Dettinger, M.D., 2002. Primary Modes and Predictability of Year-to-Year Snowpack Variations in the Western United States from Teleconnections with Pacific Ocean Climate. J. Hydrometeorol. 3, 13-25. doi:10.1175/15257541(2002)003<0013:PMAPOY>2.0.CO;2

McCabe, G.J., Dettinger, M.D., 1999. Decadal variations in the strength of ENSO teleconnections with precipitation in the western United States. Int. J. Climatol. 19, 13991410. doi:10.1002/(SICI)1097-0088(19991115)19:13<1399::AID-JOC457>3.0.CO;2-A 
1613

1614

1615

1616

1617

1618

1619

1620

1621

1622

1623

1624

1625

1626

1627

1628

1629

1630

1631

1632

1633

1634

1635

1636

1637

1638

1639

1640

1641

1642

1643

1644

1645

1646

1647

1648

1649

1650

1651

1652

1653

1654

McCabe, G.J., Palecki, M.A., Betancourt, J.L., 2004. Pacific and Atlantic Ocean influences on multidecadal drought frequency in the United States. Proc. Natl. Acad. Sci. U. S. A. 101, 4136-4141. doi:10.1073/pnas.0306738101

McGregor, H. V., Gagan, M.K., 2004. Western Pacific coral $\delta 180$ records of anomalous Holocene variability in the El Niño-Southern Oscillation. Geophys. Res. Lett. 31. doi:10.1029/2004GL019972

Mehringer Jr., P.J., Arno, S.F., Peterson, K.L., 1977. Postglacial history of Lost Trail Pass Bog, Bitterroot Mountains, Montana. Arct. Alp. Res. 9, 345-368.

Mehringer, P., Martin, P., Haynes, C., 1967. Murray Springs, a mid-postglacial pollen record from southern Arizona. Am. J. Sci. 265, 786-797.

Menking, K.M., Anderson, R.Y., 2003. Contributions of La Ni??a and El Ni??o to middle Holocene drought and late Holocene moisture in the American Southwest. Geology 31, 937-940. doi:10.1130/G19807.1

Mensing, S. a., Sharpe, S.E., Tunno, I., Sada, D.W., Thomas, J.M., Starratt, S., Smith, J., 2013. The Late Holocene Dry Period: Multiproxy evidence for an extended drought between 2800 and 1850calyr BP across the central Great Basin, USA. Quat. Sci. Rev. 78, 266-282. doi:10.1016/j.quascirev.2013.08.010

Merlivat, L., Jouzel, J., 1979. Global climatic interpretation of the deuterium-oxygen 18 relationship for precipitation. J. Geophys. Res. 84, 5029. doi:10.1029/JC084iC08p05029

Metcalfe, S.E., Barron, J.A., Davies, S.J., 2015. The Holocene history of the North American Monsoon: "known knowns" and "known unknowns" in understanding its spatial and temporal complexity. Quat. Sci. Rev. 120, 1-27. doi:10.1016/j.quascirev.2015.04.004

Mihindukulasooriya, L.N., Ortiz, J.D., Pompeani, D.P., Steinman, B.A., Abbott, M.B., 2015. Reconstruction of late Quaternary paleohydrologic conditions in southeastern British Columbia using visible derivative spectroscopy of Cleland Lake sediment. Quat. Res. 83, 531-544. doi:10.1016/j.yqres.2015.02.003

Millspaugh, S.H., Whitlock, C., Bartlein, P., 2004. Postglacial fire, vegetation, and climate history of the Yellowstone-Lamar and Central Plateau provinces, Yellowstone National Park, in: Wallace, L. (Ed.), After the Fires: The Ecology of Change in Yellowstone National Park. Yale University Press, New Haven, pp. 10-28.

Millspaugh, S.H., Whitlock, C., Bartlein, P.J., 2000. Variations in fire frequency and climate over the past $17000 \mathrm{yr}$ in central Yellowstone National Park. Geology 28, 211-214. doi:10.1130/0091-7613(2000)28<211:VIFFAC>2.0.CO;2

Minobe, S., Mantua, N., 1999. Interdecadal modulation of interannual atmospheric and oceanic variability over the North Pacific. Prog. Oceanogr. 43, 163-192. doi:10.1016/S00796611(99)00008-7

Mo, K.C., Schemm, J.-K.E., Yoo, S.-H., 2009. Influence of ENSO and the Atlantic Multidecadal Oscillation on Drought over the United States. J. Clim. 22, 5962-5982. doi:10.1175/2009JCLI2966.1

Mohtadi, M., Romero, O.E., Hebbeln, D., 2004. Changing marine productivity off northern Chile during the past 19,000 years: A multivariable approach. J. Quat. Sci. 19, 347-360. doi: $10.1002 /$ jqs. 832 
Morrill, C., 2004. The influence of Asian summer monsoon variability on the water balance of a Tibetan lake. J. Paleolimnol. 32, 273-286. doi:10.1023/B:JOPL.0000042918.18798.cb

Morrill, C., Overpeck, J.T., Cole, J.E., Liu, K.B., Shen, C., Tang, L., 2006. Holocene variations in the Asian monsoon inferred from the geochemistry of lake sediments in central Tibet. Quat. Res. 65, 232-243. doi:10.1016/j.yqres.2005.02.014

Moy, C.M., Seltzer, G.O., Rodbell, D.T., Anderson, D.M., 2002. Variability of El Niño/Southern Oscillation activity at millennial timescales during the Holocene epoch. Nature 420, $162-$ 165. doi:10.1038/nature01194

Mullineaux, D.R., 1986. Summary of pre-1980 tephra-fall deposits erupted from Mount St. Helens, Washington State, USA. Bull. Volcanol. 48, 17-26. doi:10.1007/BF01073510

Nelson, D.B., Abbott, M.B., Steinman, B., Polissar, P.J., Stansell, N.D., Ortiz, J.D., Rosenmeier, M.F., Finney, B.P., Riedel, J., 2011. Drought variability in the Pacific Northwest from a 6,000-yr lake sediment record. Proc. Natl. Acad. Sci. U. S. A. 108, 3870-3875. doi:10.1073/pnas.1009194108

Newman, M., Compo, G.P., Alexander, M.A., 2003. ENSO-Forced Variability of the Pacific Decadal Oscillation. J. Clim. 16, 3853-3857. doi:10.1175/15200442(2003)016<3853:EVOTPD $>2.0 . \mathrm{CO} ; 2$

Palmer, S., Walker, I., Heinrichs, M., Hebda, R., Scudder, G., 2002. Postglacial midge community change and Holocene palaeotemperature reconstructions near treeline, southern British Columbia (Canada). J. Paleolimnol. 28, 469-490. doi:10.1023/A:1021644122727

Pellatt, M.G., Smith, M.J., Mathewes, R.W., Walker, I.R., 1998. Palaeoecology of postglacial treeline shifts in the northern Cascade Mountains, Canada. Palaeogeogr. Palaeoclimatol. Palaeoecol. 141, 123-138. doi:10.1016/S0031-0182(98)00014-5

Pellatt, M.G., Smith, M.J., Mathewes, R.W., Walker, I.R., Palmer, S.L., 2000. Holocene treeline and climate change in the subalpine zone near Stoyoma Mountain, Cascade Mountains southwestern British Columbia, Canada. Arct. Antarct. Alp. Res. 32, 73-83. doi: $10.2307 / 1552412$

Phillips, F.M., Campbell, A.R., Smith, G.I., Bischoff, J.L., 1994. Interstadial climatic cycles: A link between western North America and Greenland? Geology 22, 1115-1118. doi:10.1130/0091-7613(1994)022

Phillips, F.M., Person, M.A., Muller, A.B., 1986. A numerical lumped-parameter model for simulating the isotopic evolution of closed-basin lakes. J. Hydrol. 85, 73-86. doi:10.1016/0022-1694(86)90077-6

Pierce, J.L., Meyer, G.A., Jull, A.J.T., 2004. Fire-induced erosion and millennial- scale climate change in northern ponderosa pine forests. Nature 432, 87-90. doi:10.1038/nature03028.Published

Power, M.J., Whitlock, C., Bartlein, P., Stevens, L.R., 2006. Fire and vegetation history during the last 3800 years in northwestern Montana. Geomorphology 75, 420-436. doi:10.1016/j.geomorph.2005.07.025

Qin, B., Harrison, S.P., Kutzbach, J.E., 1998. Evaluation of modelled regional water balance using lake status data: A comparison of 6 ka simulations with the NCAR CCM. Quat. Sci. Rev. 17, 535-548. doi:10.1016/S0277-3791(98)00011-0 
Raidt, H., Koschel, R., 1988. Morphology of calcite crystals in hardwater lakes. Limnologica 19, 3-12.

Reasoner, M.A., Hickman, M., 1989. Late Quaternary environmental change in the Lake O'Hara region, Yoho National Park, British Columbia. Palaeogeogr. Palaeoclimatol. Palaeoecol. 72, 291-316. doi:10.1016/0031-0182(89)90149-1

Reimer, P., 2013. IntCal13 and Marine13 Radiocarbon Age Calibration Curves 0-50,000 Years cal BP. Radiocarbon 55, 1869-1887. doi:10.2458/azu_js_rc.55.16947

Rein, B., Lückge, A., Reinhardt, L., Sirocko, F., Wolf, A., Dullo, W.C., 2005. El Niño variability off Peru during the last 20,000 years. Paleoceanography 20. doi:10.1029/2004PA001099

Riedinger, M.A., Steinitz-Kannan, M., Last, W.M., Brenner, M., 2002. A 6100 C-14 yr record of El Niño activity from the Galapagos Islands. J. Paleolimnol. 27, 1-7. doi:10.1023/a:1013514408468

Rimbu, N., 2003. Arctic/North Atlantic Oscillation signature in Holocene sea surface temperature trends as obtained from alkenone data. Geophys. Res. Lett. 30. doi:10.1029/2002GL016570

Rimbu, N., Lohmann, G., Lorenz, S.J., Kim, J.H., Schneider, R.R., 2004. Holocene climate variability as derived from alkenone sea surface temperature and coupled ocean-atmosphere model experiments. Clim. Dyn. 23, 215. doi:10.1007/s00382-004-0435-8

Ritchie, J.C., Harrison, S.P., 1993. Vegetation, lake levels, and climate in western Canada during the Holocene. In "Global Climates since the Last Glacial Maximum, in: Wright Jr., H.E., Kutzbach, J.E., Webb III, T., Ruddiman, W.F., Street-Perrott, F.A., Bartlein, P.J. (Eds.), Global Climates since the Last Glacial Maximum. University of Minnesota Press, Minneapolis, pp. 401-412.

Roberts, N., Jones, M.D., Benkaddour, A., Eastwood, W.J., Filippi, M.L., Frogley, M.R., Lamb, H.F., Leng, M.J., Reed, J.M., Stein, M., Stevens, L., Valero-Garcés, B., Zanchetta, G., 2008. Stable isotope records of Late Quaternary climate and hydrology from Mediterranean lakes: the ISOMED synthesis. Quat. Sci. Rev. 27, 2426-2441. doi:10.1016/j.quascirev.2008.09.005

Rodbell, D.T., Seltzer, G.O., Anderson, D.M., Abbott, M.B., Enfield, D.B., Newman, J.H., 1999. An $~ 15,000$-Year Record of El Niño-Driven Alluviation in Southwestern Ecuador. Science (80-. ). 283, 515-520.

Rosenberg, S.M., Walker, I.R., Mathewes, R.W., Hallett, D.J., 2004. Midge-inferred Holocene climate history of two subalpine lakes in southern British Columbia, Canada. The Holocene 14, 258-271. doi:10.1191/0959683604hl703rp

Rowe, H.D., Dunbar, R.B., 2004. Hydrologic-energy balance constraints on the Holocene lakelevel history of lake Titicaca, South America. Clim. Dyn. 23, 439-454. doi:10.1007/s00382004-0451-8

Rozanski, K., Araguás-Araguás, L., Gonfiantini, R., 1992. Relation between long-term trends of oxygen-18 isotope composition of precipitation and climate. Science 258, 981-985. doi:10.1126/science.258.5084.981

Sachs, J.P., 2007. Cooling of Northwest Atlantic slope waters during the Holocene. Geophys. Res. Lett. 34, 1-4. doi:10.1029/2006GL028495 
Sandweiss, D.H., Maasch, K.A., Burger, R.L., Richardson, J.B., Rollins, H.B., Clement, A., 2001. Variation in Holocene El Niño frequencies: Climate records and cultural consequences in ancient Peru. Geology 29, 603-606. doi:10.1130/00917613(2001)029<0603:VIHENO > 2.0.CO;2

Sandweiss, D.H., Richardson, J.B., Reitz, E.J., Rollins, H.B., Maasch, K.A., 1996. Geoarchaeological Evidence from Peru for a 5000 Years B.P. Onset of El Niño. Science (80-. ). doi:10.1126/science.273.5281.1531

Schmidt, G.A., Annan, J.D., Bartlein, P.J., Cook, B.I., Guilyardi, E., Hargreaves, J.C., Harrison, S.P., Kageyama, M., Legrande, A.N., Konecky, B., Lovejoy, S., Mann, M.E., MassonDelmotte, V., Risi, C., Thompson, D., Timmermann, A., Yiou, P., 2014. Using palaeoclimate comparisons to constrain future projections in CMIP5. Clim. Past 10, 221-250. doi: $10.5194 / \mathrm{cp}-10-221-2014$

Sea, D.S., Whitlock, C., 1995. Postglacial Vegetation and Climate of the Cascade Range, Central Oregon. Quat. Res. 43, 370-381. doi:10.1006/qres.1995.1043

Shanahan, T.M., Overpeck, J.T., Sharp, W.E., Scholz, C.A., Arko, J.A., 2007. Simulating the response of a closed-basin lake to recent climate changes in tropical West Africa (Lake Bosumtwi, Ghana). Hydrol. Process. 21, 1678-1691. doi:10.1002/hyp.6359

Shapley, M.D., Ito, E., Donovan, J.J., 2008. Isotopic evolution and climate paleorecords: Modeling boundary effects in groundwater-dominated lakes. J. Paleolimnol. 39, 17-33. doi:10.1007/s10933-007-9092-3

Shapley, M.D., Ito, E., Donovan, J.J., 2005. Authigenic calcium carbonate flux in groundwatercontrolled lakes: Implications for lacustrine paleoclimate records. Geochim. Cosmochim. Acta 69, 2517-2533. doi:10.1016/j.gca.2004.12.001

Shin, S.-I., Sardeshmukh, P.D., Webb, R.S., Oglesby, R.J., Barsugli, J.J., 2006. Understanding the Mid-Holocene Climate. J. Clim. 19, 2801-2817. doi:10.1175/JCLI3733.1

Shuman, B., Henderson, A.K., Colman, S.M., Stone, J.R., Fritz, S.C., Stevens, L.R., Power, M.J., Whitlock, C., 2009. Holocene lake-level trends in the Rocky Mountains, U.S.A. Quat. Sci. Rev. 28, 1861-1879. doi:10.1016/j.quascirev.2009.03.003

Shuman, B., Pribyl, P., Minckley, T.A., Shinker, J.J., 2010. Rapid hydrologic shifts and prolonged droughts in Rocky Mountain headwaters during the Holocene. Geophys. Res. Lett. 37. doi:10.1029/2009GL042196

Sondi, I., Juracic, M., 2010. Whiting events and the formation of aragonite in Mediterranean Karstic Marine Lakes: new evidence on its biologically induced inorganic origin. Sedimentology 57, 85-95. doi:10.1111/j.1365-3091.2009.01090.x

Stansell, N.D., Steinman, B. a., Abbott, M.B., Rubinov, M., Roman-Lacayo, M., 2012. Lacustrine stable isotope record of precipitation changes in Nicaragua during the Little Ice Age and Medieval Climate Anomaly. Geology 41, 151-154. doi:10.1130/G33736.1

Steinman, B.A., Abbott, M.B., 2013. Isotopic and hydrologic responses of small, closed lakes to climate variability: Hydroclimate reconstructions from lake sediment oxygen isotope records and mass balance models. Geochim. Cosmochim. Acta 105, 342-359. doi:10.1016/j.gca.2012.11.027

Steinman, B.A., Abbott, M.B., Mann, M.E., Ortiz, J.D., Feng, S., Pompeani, D.P., Stansell, N.D., 
Anderson, L., Finney, B.P., Bird, B.W., 2014. Ocean-atmosphere forcing of centennial hydroclimate variability in the Pacific Northwest. Geophys. Res. Lett. 41, 2553-2560. doi:10.1002/2014GL059499

Steinman, B.A., Abbott, M.B., Mann, M.E., Stansell, N.D., Finney, B.P., 2012. 1,500 year quantitative reconstruction of winter precipitation in the Pacific Northwest. Proc. Natl. Acad. Sci. 109, 11619-11623. doi:10.1073/pnas.1201083109

Steinman, B.A., Abbott, M.B., Nelson, D.B., Stansell, N.D., Finney, B.P., Bain, D.J., Rosenmeier, M.F., 2013. Isotopic and hydrologic responses of small, closed lakes to climate variability: Comparison of measured and modeled lake level and sediment core oxygen isotope records. Geochim. Cosmochim. Acta 105, 455-471. doi:10.1016/j.gca.2012.11.026

Steinman, B.A., Rosenmeier, M.F., Abbott, M.B., 2010a. The isotopic and hydrologic response of small, closed-basin lakes to climate forcing from predictive models: Simulations of stochastic and mean state precipitation variations. Limnol. Oceanogr. 55, 2246-2261. doi:10.4319/lo.2010.55.6.2246

Steinman, B.A., Rosenmeier, M.F., Abbott, M.B., Bain, D.J., 2010b. The isotopic and hydrologic response of small, closed-basin lakes to climate forcing from predictive models: Application to paleoclimate studies in the upper Columbia River Basin. Limnol. Oceanogr. 55, 22312245. doi:10.4319/lo.2010.55.6.2231

Steponaitis, E., Andrews, A., McGee, D., Quade, J., Hsieh, Y.-T., Broecker, W.S., Shuman, B.N., Burns, S.J., Cheng, H., 2015. Mid-Holocene drying of the U . S . Great Basin recorded in Nevada speleothems. Quat. Sci. Rev. 1-12. doi:10.1016/j.quascirev.2015.04.011

Stone, J.R., Fritz, S.C., 2006. Multidecadal drought and Holocene climate instability in the Rocky Mountains. Geology 34, 409-412. doi:10.1130/G22225.1

Stott, L., Cannariato, K., Thunell, R., Haug, G.H., Koutavas, A., Lund, S., 2004. Decline of surface temperature and salinity in the western tropical Pacific Ocean in the Holocene epoch. Nature 431, 56-59. doi:10.1038/nature02903

Stott, L., Timmermann, A., Thunell, R., 2007. Southern Hemisphere and deep-sea warming led deglacial atmospheric CO2 rise and tropical warming. Science 318, 435-438. doi: $10.1126 /$ science. 1143791

Sung, M.-K., An, S.-I., Kim, B.-M., Woo, S.-H., 2014. A physical mechanism of the precipitation dipole in the western United States based on PDO-storm track relationship. Geophys. Res. Lett. 41, 4719-4726. doi:10.1002/2014GL060711

Talbot, M.R., 1990. A review of the palaeohydrological interpretation of carbon and oxygen isotopic ratios in primary lacustrine carbonates. Chem. Geol. Isot. Geosci. Sect. 80, 261279. doi:10.1016/0168-9622(90)90009-2

Talbot, M.R., Kelts, K., 1990. Paleolimnological Signatures from Carbon and Oxygen Isotopic Ratios in Carbonates from Organic Carbon-Rich Lacustrine Sediments, in: Lacustrine Basin Exploration : Case Studies and Modern Analogs. pp. 99-112.

Tate, E., Sutcliffe, J., Conway, D., Farquharson, F., 2004. Water balance of Lake Victoria: update to 2000 and climate change modelling to 2100 . Hydrol. Sci. J. 49, 563-574. doi:10.1623/hysj.49.4.563.54422 
1823

1824

1825

1826

1827

1828

1829

1830

1831

1832

1833

1834

1835

1836

1837

1838

1839

1840

1841

1842

1843

1844

1845

1846

1847

1848

1849

1850

1851

1852

1853

1854

1855

1856

1857

1858

1859

1860

1861

1862

1863

Taylor, K.E., Stouffer, R.J., Meehl, G.A., 2012. An Overview of CMIP5 and the Experiment Design. Bull. Am. Meteorol. Soc. 93, 485-498. doi:10.1175/BAMS-D-11-00094.1

Thompson, J.B., Schultze-Lam, S., Beveridge, T.J., Des Marais, D.J., 1997. Whiting events: biogenic origin due to the photosynthetic activity of cyanobacterial picoplankton. Limnol. Oceanogr. 42, 133-141. doi:10.4319/lo.1997.42.1.0133

Thornthwaite, C.W., 1948. An Approach Toward a Rational Classification of Climate. Soil Sci. 66, 77. doi:10.1097/00010694-194807000-00007

Timmermann, A., Okumura, Y., An, S.I., Clement, A., Dong, B., Guilyardi, E., Hu, A., Jungclaus, J.H., Renold, M., Stocker, T.F., Stouffer, R.J., Sutton, R., Xie, S.P., Yin, J., 2007. The influence of a weakening of the Atlantic meridional overturning circulation on ENSO. J. Clim. 20, 4899-4919. doi:10.1175/JCLI4283.1

Troin, M., Vallet-Coulomb, C., Sylvestre, F., Piovano, E., 2010. Hydrological modelling of a closed lake (Laguna Mar Chiquita, Argentina) in the context of 20th century climatic changes. J. Hydrol. 393, 233-244. doi:10.1016/j.jhydrol.2010.08.019

Trouet, V., Taylor, A.H., 2010. Multi-century variability in the Pacific North American circulation pattern reconstructed from tree rings. Clim. Dyn. 35, 953-963. doi:10.1007/s00382-009-0605-9

Tudhope, A.W., Chilcott, C.P., McCulloch, M.T., Cook, E.R., Chappell, J., Ellam, R.M., Lea, D.W., Lough, J.M., Shimmield, G.B., 2001. Variability in the El Niño-Southern Oscillation through a glacial-interglacial cycle. Science 291, 1511-1517. doi:10.1126/science. 1057969

Valiantzas, J.D., 2006. Simplified versions for the Penman evaporation equation using routine weather data. J. Hydrol. 331, 690-702. doi:10.1016/j.jhydrol.2006.06.012

Vallet-Coulomb, C., Gasse, F., Robison, L., Ferry, L., Van Campo, E., Chalié, F., 2006. Hydrological modeling of tropical closed Lake Ihotry (SW Madagascar): Sensitivity analysis and implications for paleohydrological reconstructions over the past 4000 years. J. Hydrol. 331, 257-271. doi:10.1016/j.jhydrol.2006.05.026

Vassiljev, J., 1998a. Simulating the Holocene lake-level record of Lake Bysjon, southern Sweden. Quat. Res. 49, 62-71. doi:10.1006/qres.1997.1942

Vassiljev, J., 1998b. The simulated response of lakes to changes in annual and seasonal precipitation: Implication for Holocene lake-level changes in northern Europe. Clim. Dyn. 14, 791-801. doi:10.1007/s003820050255

Verdon, D.C., Franks, S.W., 2006. Long-term behaviour of ENSO: Interactions with the PDO over the past 400 years inferred from paleoclimate records. Geophys. Res. Lett. 33. doi:10.1029/2005GL025052

Vimont, D.J., 2005. The Contribution of the Interannual ENSO Cycle to the Spatial Pattern of Decadal ENSO-Like Variability. J. Clim. 18, 2080-2092. doi:10.1175/JCLI3365.1

Wallace, J.M., Thompson, D.W.J., 2002. The Pacific Center of Action of the Northern Hemisphere Annular Mode: Real or Artifact? J. Clim. 15, 1987-1991. doi:10.1175/15200442(2002)015<1987:TPCOAO $>2.0 . \mathrm{CO} ; 2$

Wang, X.L., Wan, H., Swail, V.R., 2006. Observed Changes in Cyclone Activity in Canada and Their Relationships to Major Circulation Regimes. J. Clim. 19, 896-915. 
Waters, M.R., 1989. Late Quaternary lacustrine history and paleoclimatic significance of pluvial Lake Cochise, southeastern Arizona. Quat. Res. doi:10.1016/0033-5894(89)90027-6

Weng, C., Jackson, S.T., 1999. Late Glacial and Holocene vegetation history and paleoclimate of the Kaibab Plateau, Arizona. Palaeogeogr. Palaeoclimatol. Palaeoecol. 153, 179-201. doi:10.1016/S0031-0182(99)00070-X

Whitfield, P.H., Moore, R.D. (Dan), Fleming, S.W., Zawadzki, A., 2010. Pacific Decadal Oscillation and the Hydroclimatology of Western Canada-Review and Prospects. Can. Water Resour. J. 35, 1-28. doi:10.4296/cwrj3501001

Whitlock, C., 1993. Postglacial Vegetation and Climate of Grand Teton and Southern Yellowstone National Parks. Ecol. Monogr. 63, 173-198. doi:10.2307/2937179

Whitlock, C., 1992. Vegetational and climatic history of the Pacific Northwest during the last 20,000 years: implications for understanding present-day biodiversity. Northwest Environ. J. 8, 5-28.

Whitlock, C., Bartlein, P.J., 1993. Spatial Variations of Holocene Climatic Change in the Yellowstone Region. Quat. Res. 39, 231-238. doi:10.1006/qres.1993.1026

Whitlock, C., Briles, C.E., Fernandez, M.C., Gage, J., 2011. Holocene vegetation, fire and climate history of the Sawtooth Range, central Idaho, USA. Quat. Res. 75, 114-124. doi:10.1016/j.yqres.2010.08.013

Whitlock, C., Brunelle, A., 2006. Pollen records from northwestern North America, in: Elias, S. (Ed.), Encyclopedia of Quaternary Science. Elsevier, Amsterdam, pp. 1170-1178.

Whitlock, C., Dean, W.E., Fritz, S.C., Stevens, L.R., Stone, J.R., Power, M.J., Rosenbaum, J.R., Pierce, K.L., Bracht-Flyr, B.B., 2012. Holocene seasonal variability inferred from multiple proxy records from Crevice Lake, Yellowstone National Park, USA. Palaeogeogr. Palaeoclimatol. Palaeoecol. 331-332, 90-103. doi:10.1016/j.palaeo.2012.03.001

Wigand, P.E., 1987. Diamond Pond, Harney County, Oregon: vegetation history and water table in the eastern Oregon desert. West. North Am. Nat. 47, 427-458.

Wise, E.K., 2010. Spatiotemporal variability of the precipitation dipole transition zone in the western United States. Geophys. Res. Lett. 37. doi:10.1029/2009GL042193

Yamaguchi, D.K., 1985. Tree-ring evidence for a two-year interval between recent prehistoric explosive eruptions of Mount St. Helens. Geology 13, 554-557. doi:10.1130/00917613(1985)13

Yukimoto, S., Adachi, Y., Hosaka, M., Sakami, T., Yoshimura, H., Hirabara, M., Tanaka, T.Y., Shindo, E., Tsujino, H., Deushi, M., Mizuta, R., Yabu, S., Obata, A., Nakano, H., Koshiro, T., Ose, T., Kitoh, A., 2012. A New Global Climate Model of the Meteorological Research Institute: MRI-CGCM3 -Model Description and Basic Performance-. J. Meteorol. Soc. Japan 90A, 23-64. doi:10.2151/jmsj.2012-A02

Zdanowicz, C.M., Zielinski, G.A., Germani, M.S., 1999. Mount Mazama eruption: Calendrical age verified and atmospheric impact assessed. Geology 27, 621-624. doi:10.1130/00917613(1999)027<0621:MMECAV>2.3.CO;2

Zebiak, S.E., Cane, M.A., 1987. A model El Niño-Southern Oscillation. Mon. Weather Rev. 115, 
1906 Zhang, R., Delworth, T.L., 2007. Impact of the Atlantic Multidecadal Oscillation on North

1907 Pacific climate variability. Geophys. Res. Lett. 34. doi:10.1029/2007GL031601

1908 Zheng, W., Braconnot, P., Guilyardi, E., Merkel, U., Yu, Y., 2008. ENSO at 6ka and $21 \mathrm{ka}$ from

1909

1910 ocean-atmosphere coupled model simulations. Clim. Dyn. 30, 745-762.

1911 Zuber, A., 1983. On the environmental isotope method for determining the water balance components of some lakes. J. Hydrol. 61, 409-427. doi:10.1016/0022-1694(83)90004-5 